\title{
THERMAL CONDUCTIVITY OF CARBON FOAM
}

J. D. Lore

H. L. Richards

M. E. Ward

September 1974

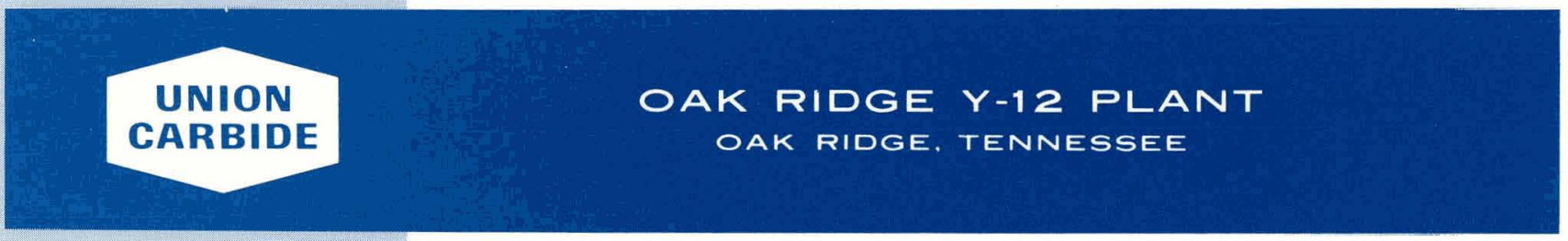

prepared for the U.S. ATOMIC ENERGY COMMISSION

under U.S. GOVERNMENT Contract W.7405 eng 26 


\section{DISCLAIMER}

This report was prepared as an account of work sponsored by an agency of the United States Government. Neither the United States Government nor any agency Thereof, nor any of their employees, makes any warranty, express or implied, or assumes any legal liability or responsibility for the accuracy, completeness, or usefulness of any information, apparatus, product, or process disclosed, or represents that its use would not infringe privately owned rights. Reference herein to any specific commercial product, process, or service by trade name, trademark, manufacturer, or otherwise does not necessarily constitute or imply its endorsement, recommendation, or favoring by the United States Government or any agency thereof. The views and opinions of authors expressed herein do not necessarily state or reflect those of the United States Government or any agency thereof. 


\section{DISCLAIMER}

Portions of this document may be illegible in electronic image products. Images are produced from the best available original document. 
Reference to a company or product name does not imply approval or recommendation of the product by Union Carbide Corporation or the U.S. Atomic Energy Commission to the exclusion of others that may meet specifications.

Printed in the United States of America. Available from National Technical Information Service

U.S. Department of Commerce

5285 Port Royal Road, Springfield, Virginia 22151

Price: Printed Copy $\$ 4.00$; Microfiche $\$ 1.45$

This report was prepared as an account of work sponsored by the United States Government. Neither the United States nor the United States Atomic Energy Commission, nor any of their employees, nor any of their contractors, subcontractors, or their employees, makes any warranty, express or implied, or assumes any legal liability or responsibility for the accuracy, completeness or usefulness of any information, apparatus, product or process disclosed, or represents that its use would not infringe privately owned rights. 


\title{
THERMAL CONDUCTIVITY OF CARBON FOAM
}

\author{
J. D. Lore \\ H. L. Richards \\ M. E. Ward \\ Laboratory Development Department \\ Y.12 Development Division
}

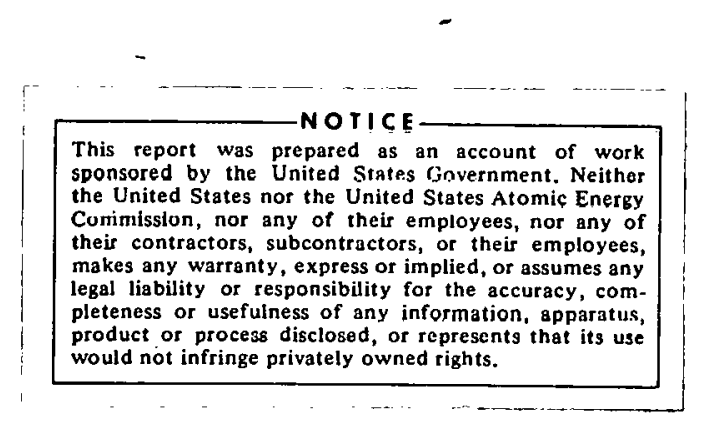

Oak Ridge Y-12 Plant

P.O. Box Y, Oak Ridge, Tennessee 37830

Prepared for the UIS. Atomic Energy Commission Under U.S. Government Conrract W.7405eng-26 


\begin{abstract}
Carbon foam materials, carbonized to $1273 \mathrm{~K}$ and graphitized to $3273 \mathrm{~K}$ prior to testing, were evaluated for thermal conductivity by three steady-state techniques: guarded hot plate, comparative apparatus, and radial flow. Tests were conducted over the temperature interval from 300 to $2800 \mathrm{~K}$. Analyses were made of the material fabrication parameters, pertinent physical properties, and employed test techniques. Interpretation of data and a comparison with the findings of other laboratories were accomplished.
\end{abstract}




\section{CONTENTS}

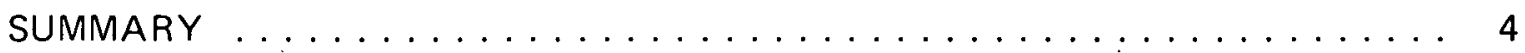

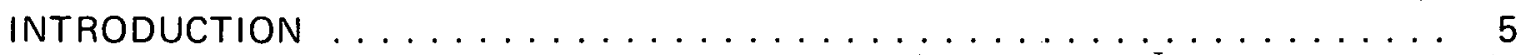

DETERMINING THE THERMAL CONDUCTIVITY OF CARBON FOAM $\ldots \ldots \ldots$

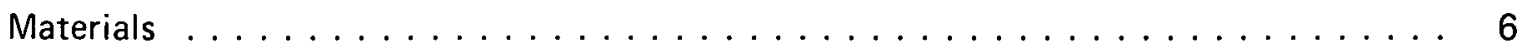

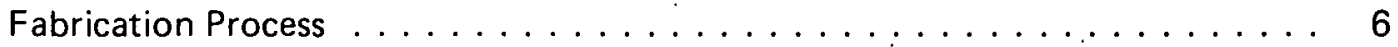

Pertinent Physical Properties . . . . . . . . . . . . . . . . . . 6

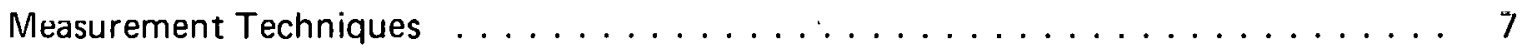

Guarded Hot Plate . . . . . . . . . . . . . . . . . . . . . 7

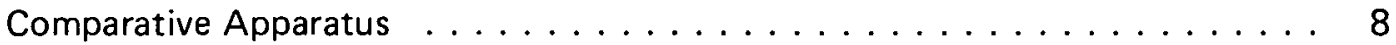

Radial Outflow ........................ 9

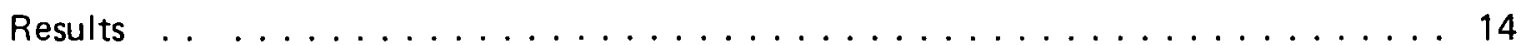

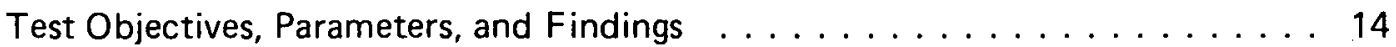

Reduction and Analysis of Data . . . . . . . . . . . . . 14

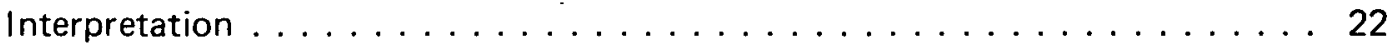

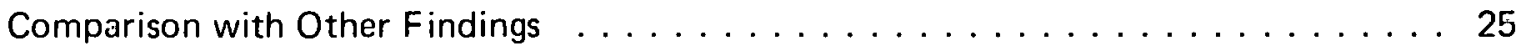

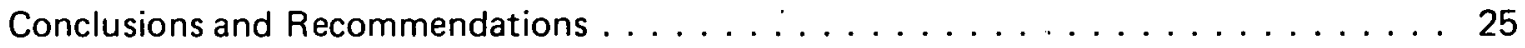

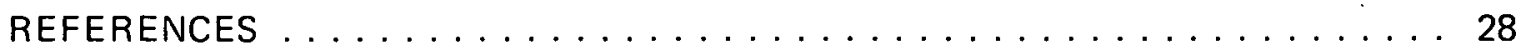

ACKNOWLEDGEMENTS $\ldots \ldots \ldots \ldots \ldots \ldots \ldots \ldots \ldots \ldots \ldots \ldots \ldots$ 


\section{SUMMARY}

Carbon foam, a cellular material of low density and relatively high compressive strength, is employed for load bearing and insulative aerospace applications. The thermophysical character of carbon foam, relativey obscure (particularly at high temperatures), is of interest for design and engineering applications. Carbon foam materials, carbonized to $1273 \mathrm{~K}$ and graphitized to $3273 \mathrm{~K}$ prior to testing, were evaluated for thermal conductivity in a nitrogen environment from 300 to $2800 \mathrm{~K}$ by several overlapping techniques. Continuous functions of temperature for thermal conductivity were determined, and comparisons were made with the findings of other laboratories for similar materials. 


\section{INTRODUCTION}

Carbon foam is a rigid, cellular material consisting of carbonized polyurethane-polyfurfuryl alcohol mixtures. Processed castings have been employed as a structural and insulation material in high-temperature applications. Carbon foam exhibits an excellent strength-toweight ratio, a superior thermal stability compared to organic foam systems, a low thermal conductivity, and a low linear coefficient of thermal expansion. The material (relatively new, unique, and potentially useful in aerospace applications) has been prepared by several investigators $(1-4)$ and described in some detail. $(5,6)$ The material's thermophysical character, a primary consideration in insulative applications, is virtually undocumented. The temperature dependency of thermal conductivity over the 300 to $2800 \mathrm{~K}$ interval is the subject of this report. 


\section{DETERMINING THE THERMAL CONDUCTIVITY OF CARBON FOAM}

\section{MATERIALS}

\section{Fabrication Process}

Carbon foam material, typical of recent production formulations, was prepared from a two-component rigid urethane system to which polymerized turturyl alcohol was added.(8) The exact formulation depends upon the desired product density. Cylindrical test billets, $250 \mathrm{~mm}$ in diameter by $430 \mathrm{~mm}$ long, were cast by pouring the organic-aqueous mixture into an aluminum mold at $323 \mathrm{~K}$. The foaming process and rising of the casting was completed in the mold to produce the so-called "green" billet which was cured at room temperature for 10 to 15 days. Converting the green castings to carbon foam was carried out in furnaces having an inert (nitrogen) atmosphere. Two castings were produced, as just described, taılorıng the manufacturing parameteris to produce nominal $220 \mathrm{~kg} / \mathrm{m}$ J materlal. One casting was carbonized to $1273 \mathrm{~K}$ after a 60 -hour treatment, another was graphitized to $3273 \mathrm{~K}$ after a 10-day treatment. Both were sectioned for physical properties testing.

\section{Pertinent Physical Properties}

Porosimetry analyses were conducted on both the carbon foam billet heat treated to $1273 \mathrm{~K}$ for "low-fired" (LF) material and also on the casting treated to $3273 \mathrm{~K}$ or "high-fired" (HF) material. The findings are summarized in Table 1.

Table 1

PERTINENT PHYSICAL PROPERTIES OF CARBON FOAM BASED ON POROSIMETRIC ANALYSES

\begin{tabular}{|c|c|c|c|c|}
\hline \multirow[b]{2}{*}{ Physical Property(1) } & \multicolumn{2}{|c|}{$\begin{array}{c}1273 \mathrm{~K} \text { Heat Treatment } \\
\text { (low fired) }\end{array}$} & \multicolumn{2}{|c|}{$\begin{array}{c}3273 \text { K Heat Treatment } \\
\text { (high-fired) }\end{array}$} \\
\hline & $\begin{array}{c}\text { Mean } \\
\text { Value }(2)\end{array}$ & $\begin{array}{c}\text { Standard } \\
\text { Deviation, } \\
\sigma(3)\end{array}$ & $\begin{array}{c}\text { Mean } \\
\text { Value (2) }\end{array}$ & $\begin{array}{c}\text { Standard } \\
\text { Deviation, } \\
\sigma(3)\end{array}$ \\
\hline Sample Weight $\langle q\rangle$. & $0,0,0519$ & 0.0140 & 0.0534 & 0.004 \\
\hline Apparent Density $(4)\left(\mathrm{kg} / \mathrm{m}^{3}\right)$ & 210 & 40 & 260 & 20 \\
\hline Bulk Density $(5)\left(\mathrm{kg} / \mathrm{m}^{3}\right)$ & 387 & 166 & 400 & 35 \\
\hline Real Density $(6)\left(\mathrm{kg} / \mathrm{m}^{3}\right)$ & 1590 & 307 & 1670 & 82 \\
\hline Porosity less than $10 \mu \mathrm{m}(\%)$ & 21.42 & 22.63 & 18.99 & 10.24 \\
\hline Tutal Operı Púrusity (88) & 77.73 & 10.05 & 75.91 & 2.67 \\
\hline Surface Area $\left(\mathrm{m}^{2} / \mathrm{g}\right)$ & 3.197 & 3.322 & 2.486 & 2.203 \\
\hline Volume-Average Equivalent Pore Diameter $(7)(\mu \mathrm{m})$ & 44.23 & 12.90 & 39.44 & 11.21 \\
\hline
\end{tabular}

(1) Measurements obtained using the Aminco porosime ter.

(2) Average for 26 observations on samples extracted from locations uniformly distributed throughout a $250-\mathrm{mm}$-diameter, $430 \mathrm{~mm}-$ long cylindrical billet.

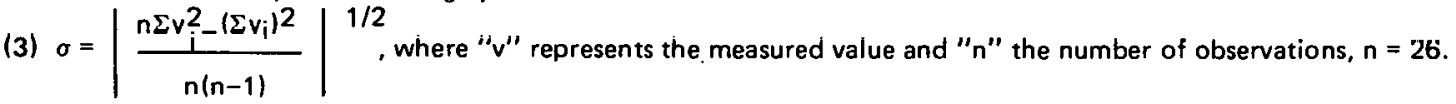

(4) Based on the sample weight prior to testing.

(5) Obtained by infiltration of all surface pores greater than $300 \mu \mathrm{m}$ in diameter.

(6) Value for the carbon matrix.

(7) Median value for both cellular axes, based on the pore volume. 
Large variations in the surface area and pore diameter throughout each billet were evidenced, and other physical dissimilarities may be noted; but, for test purposes, the LF and HF materials are herein considered as roughly equivalent except for the extent of heat treatment. It is felt that the $3273 \mathrm{~K}$ treatment (ie, extensive graphitization) gave rise to the major porosimetric differences between the LF and HF materials.

\section{MEASUREMENT TECHNIQUES}

\section{Guarded Hot Plate}

A guarded hot plate (GHP)(7) (Dynatech Model TCFGM-N18) was employed for the low-temperature (300-1000 K) measurements of thermal conductivity. The instrument test section, as depicted in Figure 1, consists of an inner (main) heater sur: rounded by an annular guard heater. Function of the guard heater is to eliminate radial heat losses and to force the heat generated in the main heater to flow in one direction through the two test samples. Auxiliary outer guard heaters are inserted between the samples (203-mm-diameter by

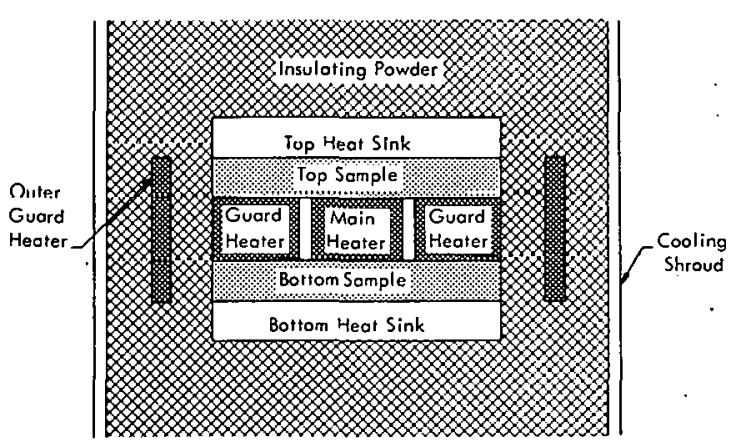

Figure 1. TEST SECTION OF THE GUARDED HOT PLATE. 25-mm-thick, solid cylinders) and the heat sinks. In this fashion, the sample temperature can be raised to any value merely by adjusting the power to the auxiliary heaters. For tests above $700 \mathrm{~K}$, a cylindrical outer guard heater is placed around the entire test section to minimize radial heat losses and to facilitate control of the guard section of the hot plate. The, entire test assembly is surrounded by a liquid-cooled shroud, and the space between the shroud and test stack is filled with insulating powder.

When the test section has reached thermal equilibrium, the temperature difference across the two samples and the electrical input to the main heater are measured and used to calculate the thermal conductivity of the sample material as follows:

$$
\lambda_{\text {avg }}=\frac{Q_{\text {total }}}{A}\left|\frac{1}{\left(\frac{\Delta T}{\Delta l}\right)_{\text {top sample }}+\left(\frac{\Delta T}{\Delta l}\right)_{\text {bottom sample }}}\right|
$$

where:

$\lambda_{\text {avg represents the average thermal conductivity of the two samples }}$ (watts/m - K).

Qtotal the total input to the main heater (watts),

A the cross-sectional area of the main heater $\left(\mathrm{m}^{2}\right)$,

$\Delta T$ the temperature difference across the sample $(K)$, and

$\Delta \ell \quad$. the sample thickness $(\mathrm{m})$. 
Conductivities ranging from 0.02 to 2 watt $/ \mathrm{m}-\mathrm{K}$ have been successfully measured. ( 8 )

All measurements on carbon foam were obtained in a nitrogen environment at a pressure slightly positive $(1.7 \mathrm{kPa})$ with respect to the ambient surroundings. Measurements were made over the temperature interval from 300 to $\sim 1000 \mathrm{~K}$.

\section{Comparative Apparatus}

A comparative-apparatus (CA) method has been employed for insulation materials as a secondary means for measurement which is especially useful for diminutive specimens. $(9,10)$ The method is essentially a compromise for materials with intermediate thermal conductivities $(0.2$ to 100 watt $/ \mathrm{m}-\mathrm{K})$, but it overlaps the GHP range and was applied as a supporting analysis for carbon foam. A drawing of the test section is presented in Figure 2. The sample geometry was a solid cylinder $(25 \mathrm{~mm}$ in diameter by $64 \mathrm{~mm}$ thick) which was sandwiched between two similar samples of a standard reference material (Pyroceram Code 9606). Heaters above and below the samples establish the temperature gradients and overall temperatures. Radial losses from the stack are avoided by controlling the temperature profile down an outer guard tube so that it matches the gradient in the composite sample stack. At equilibrium, assuming that the heat flow along the length

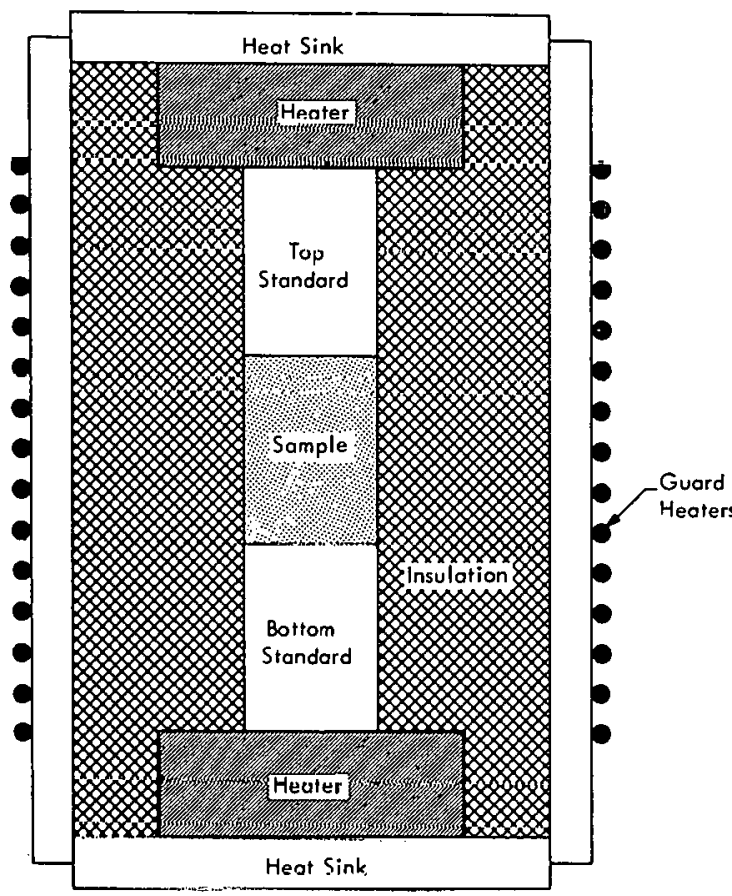

Figure 2. TEST SECTION OF THE COMPARATIVE APPARATUS. of the stack is uniform and constant, the conditions for measurement are met.

The temperature difference $(\Delta T)$ is related to the amount of heat, $q$ (watt), according to Fourier's heat conduction equation: (11)

$$
\Delta T=\frac{\Delta \ell}{\lambda}\left(\frac{q}{A}\right)
$$

where:

$\Delta \ell$ represents the distance between the two temperature-measuring points,

A the area of the cross section perpendicular to the direction of heat flow, and

$\lambda$ the coefficient of thermal conductivity. 
It is quite obvious from Equation 2 that when the quantity $(q / A)$ is kept the same for two materials-one of known thermal conductivity ( $\lambda$ reference) and one of unknown thermal conductivity $\left(\lambda_{\text {sample }}\right)$-the respective temperature drops are related as follows:

$$
\Delta T\left(\frac{\lambda}{\Delta l}\right)_{\text {sample }}=\Delta T\left(\frac{\lambda}{\Delta l}\right)_{\text {reference }}
$$

Thus, by measuring the temperature difference between the two thermocouples a distance $\Delta \ell$ apart in both the reference material and test sample, the unknown thermal conductivity is:

$$
\lambda_{\text {sample }}=\left(\frac{\lambda \Delta T}{\Delta \ell}\right)_{\text {reference }} \times\left(\frac{\Delta \ell}{\Delta T}\right)_{\text {sample }}
$$

The condition of equal heat flux [or heat-flow density $(q / A)$ ] is obtained by placing a test sample and reference material of equal cross section in intimate contact with each other and by holding the two between a heater and a heat sink (Figure 2). Tests on carbon foam were conducted in a nitrogen environment at a positive pressure of approximately $1.7 \mathrm{kPa}$ over the temperature interval from 400 to $\sim 1100 \mathrm{~K}$.

\section{Radial Outflow}

High-temperature measurements of thermal conductivity were acquired using a radial-flow (RF) apparatus constructed after the design of Wagner(12) as LASL. The technique and its application to carbonaceous material have been fully described.(13) The primary reported use of the LASL instrument has been to test graphites for nuclear rocket and reactor applications. $(14-16)$

This report details the initial application of the radial outflow technique to a material such as carbon foam. A functional description of the apparatus has been made in order to clarify this "nonstandard" test application, but much of the procedural detail should be attributed to the original investigator. $(12,13)$

An overview of the high-temperature thermal conductivity testing facility and a schematic of the employed furnace are provided in Figures 3 and 4. The RF apparatus is located in the central area just to the left of the control panel (Figure 3) which contains potentiometric controls for the $50 \mathrm{kVA}$, three-phase, DC power source (Miller SR-1000-A7) which supplies the resistively heated, water-cooled furnace. Current is passed through a solid cylinder (12.7 $\mathrm{mm}$ in diameter by $165 \mathrm{~mm}$ long) shown in Figure 5 (far right). The adjacent specimen-to-heater rod assembly is accomplished by rod insertion into the hollow cylindrical specimen ( $12.8 \mathrm{~mm}$ ID by $25.4 \mathrm{~mm}$ OD by $89.0 \mathrm{~mm}$ long), as illustrated. The assembly is then secured in the furnace, as viewed in Figure 6 , having been press fitted into the graphite (Grade ATJ) grips which are connected to the positive and negative electrode terminal feedthroughs. The water-cooled electrodes receive power directly from the supply which is connected by flat-faced bus bars and electrical cables (Size 1 wire). Measurement of the applied power requires a voltage drop measurement $(v)$ over the middle $17.0 \mathrm{~mm}$ length $(\ell)$ of the specimen. This measurement is accomplished by employing two pointed graphite voltage probes (Grade UF4S) which make contact at the heater rod surface passing through the specimen. 


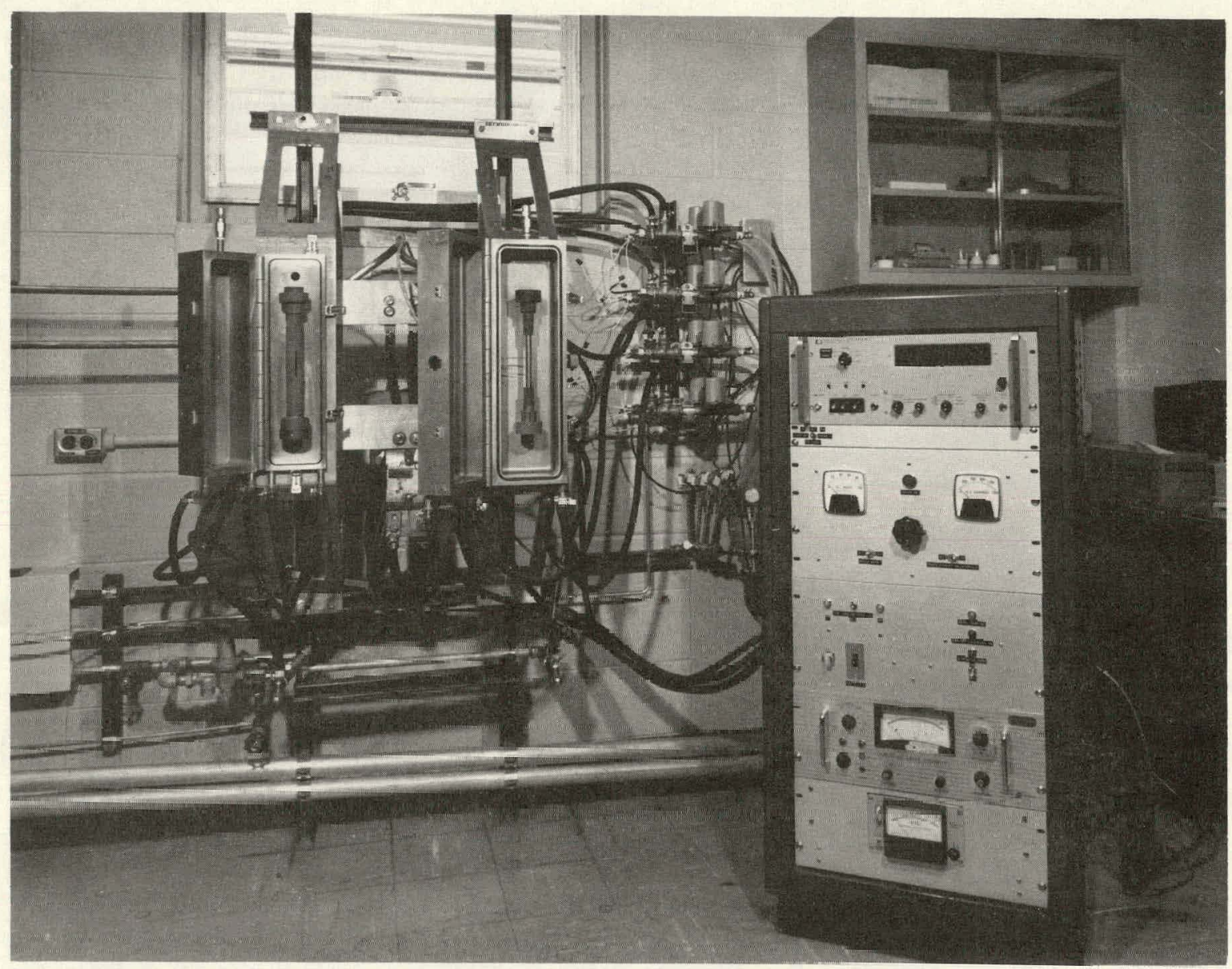

FIgure 3. HIGH-TEMPERATURE TLGTING FACILITY.

130820

The probes are supported in the furnace wall and are fed through to electrical leads and inputted to an integrating-type digital voltmeter (Figure 6). Current (i) is measured by inserting a precision air-cooled shunt in series with the power train and measuring the voltage drop across the shunt. Energy supplied to the specimen by the rod instills a radial-outflow condition. The outer surface of the test specimen loses energy to the surrounding graphite-coated (Dylon A.E), cold, black furnace wall predominantly by radiation and, thus, a temperature gradient is set up through the wall of the hollow cylinder.

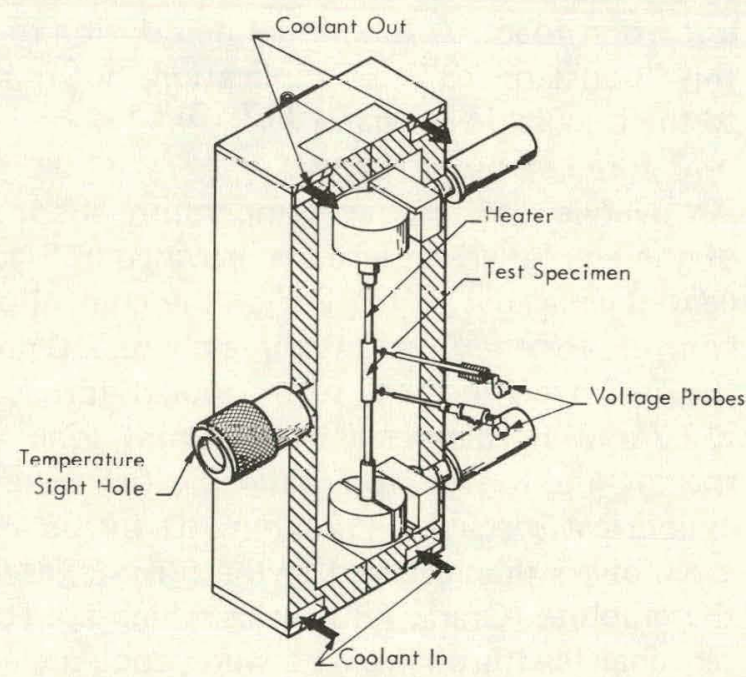

Figure 4. BOX-FURNACE, RADIAL-HEAT-FLOW, THERMAL-CONDUCTIVITY ARRANGEMENT. 


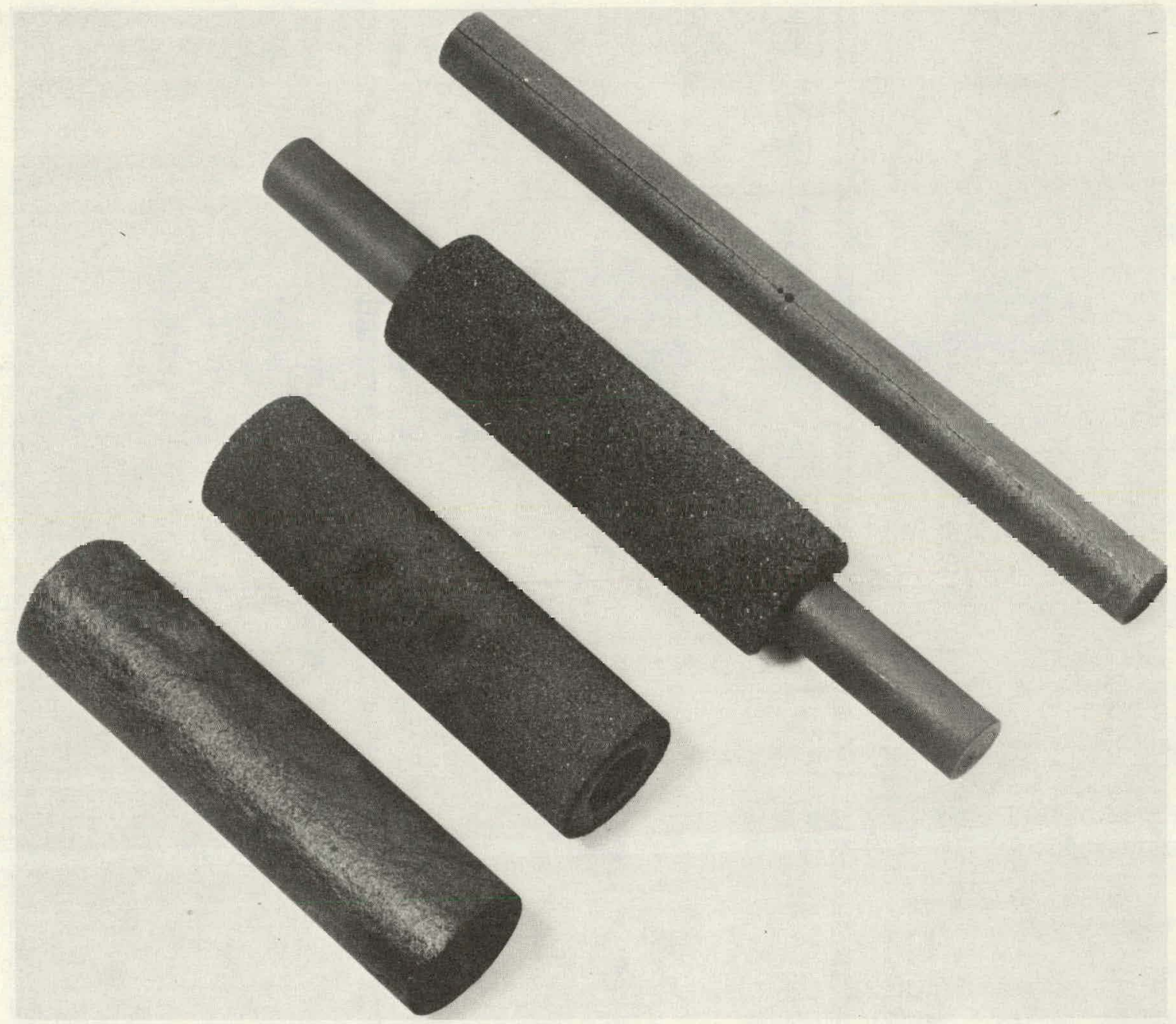

134779

Figure 5. HIGH-TEMPERATURE THERMAL CONDUCTIVITY TEST SPECIMENS.

Equation 2 may be restated in terms of thermal energy, $\mathrm{Q}$ (joulcs), as:

$$
\mathrm{Q}=\lambda A \mathrm{t} \frac{\Delta T}{\Delta s}
$$

where:

t represents the transport time (s),

A the area measured at right angles to the direction of heat flow for this condition $\left(\mathrm{m}^{2}\right)$, and

$\Delta T$ the difference in temperature $(k)$ between two parallel surfaces a distance, $\Delta s$, apart. 


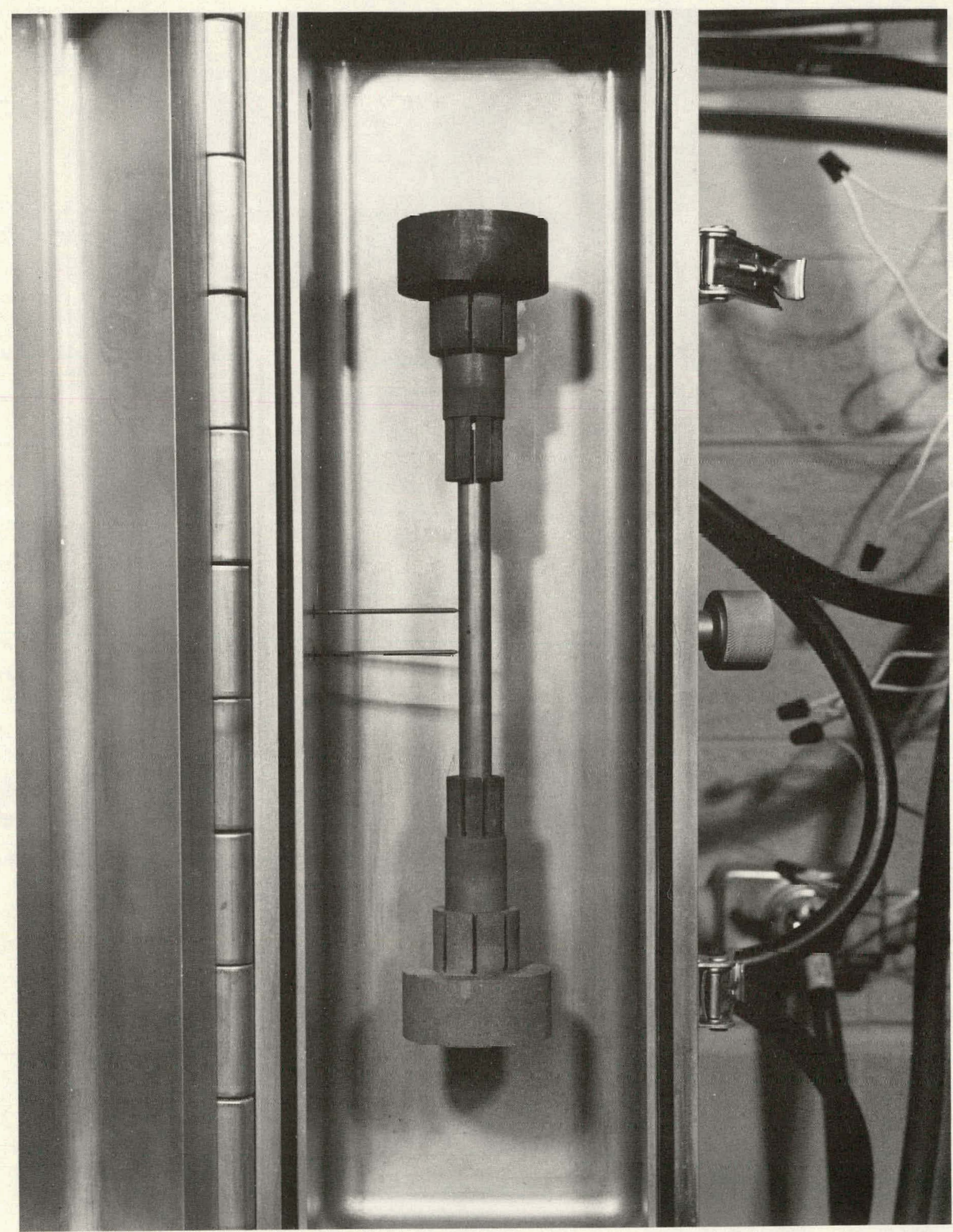

130819

Figure 6. RADIAL-FLOW TEST SECTION. 
A general equation for steady, one-dimensional (radial) flow can be inferred from Equation 5 as:

$$
\frac{d Q}{d t}=-\lambda A \frac{d T}{d s}
$$

where the minus sign is introduced because the temperature decreases in the direction of heat flow.

Further:

$$
\frac{d Q}{d t}=i v=P(w a t t)
$$

where $P$ is a constant under steady-state conditions.

For a hollow cylinder, as depicted in Figure 7 , the cylindrical shell has a surface area represented by:

$$
A=2 \pi r \ell,
$$

where $\ell$ represents the included axial distance $(m)$ and $r=s=$ the transport distance $(m)$. Substituting for $s$ and $A$ in Equation 6 gives:

$$
\frac{P d r}{r}=-2 \pi \lambda \ell d T
$$

Integration between limits will yield an expression for the thermal conductivity $(\lambda)$ :

$$
\lambda=\frac{P \ln \frac{r_{2}}{r_{1}}}{2 \pi \ell\left(T_{1}-T_{2}\right)} .
$$

Equation 10 was employed to compute the radial flow $\lambda$ values.

Four 0.76-mm-diameter pyrometer sighting holes were drilled at the approximate centerline of the gage section to the depths indicated in Figure 7. This geometrical comfiguration facilitated four observations of temperature $\left(T_{1}, T_{2}, T_{3}, T_{4}\right)$ at each furnace power setting at four incremental radial sites $\left(r_{1}, r_{2}, r_{3}, r_{4}\right)$ extending outward from the cylindrical specimen's axis. Temperature measurements were obtained using a single, disappearing, filament-type, micro-optical pyrometer (Pyro 95) operating at the nominal red wavelength $(650 \mathrm{~nm})$ and calibrated with a black body source. Responses were corrected for the interviewing media (quartz window and, the ambient nitrogen test environment) at $1.7 \mathrm{kPa}$. 


\section{RESULTS}

Test Objectives, Parameters, and Findings

Employment of materials such as carbon foam for load bearing and insulative aerospace applications is dependent on the combination of a low thermal conductivity, inertness at high temperatures, a low density and chemical compatibility with other carbon-based materials. These requirements necessitate a thermophysical characterization of candidate materials from room

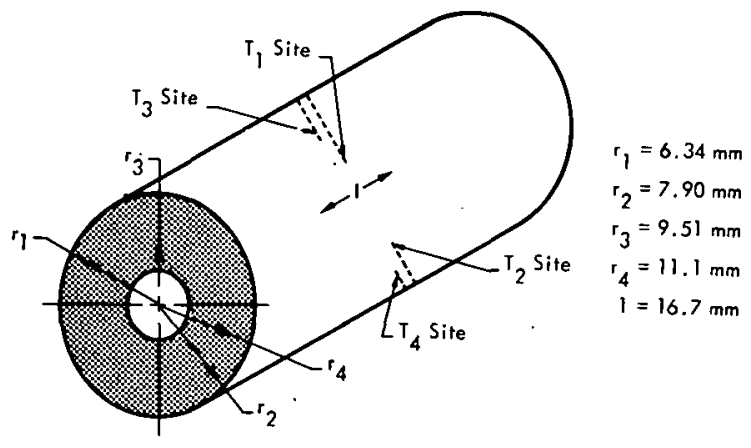

Figure 7. HOLLOW, CYLINDRICAL, RADIAL.FLOW TEST SPECIMEN. temperature to their destruction tempera= ture.

Test specimens of the low and high-fired carbon foam were evaluated for thermal conductivity by the techniques just described. All measurements were made in a direction perpendicular to the axis of cell rise, as indicated in Figure 8-a cell cross section depicted somewhat simplistically as an ellipsoid. Tests were conducted in a nitrogen environment at $+1.7 \mathrm{kPa}$. Thermal-conductivity results for the nominal $220 \mathrm{~kg} / \mathrm{m}^{3}$ carbon foam are compiled in Tables 2 and 3 and are illustrated in Figures $9-11$.

\section{Reduction and Analysis of Data}

Thermal conductivity values, as given in Tables 2 and 3, are based on the aqqreqation and réduction of $\mathrm{GHP}, \mathrm{CA}$, and $\overline{\mathrm{R} F}$ results, considered separately. Data compiled therein are represented both as observations and as values computed by regression analyses. Continunus thermal conductivity functions of temperature are also tabulated as an empirical means of generating average values for comparison at a given temperature.

These computed values for the GHP technique were at variance with the observed values by as much as $7.3 \%$ for the LF material and as little as $1.8 \%$ for the HF material. Thus, the empirical least-squares analyses of GHP results gave the least and most pres.ise mathematical

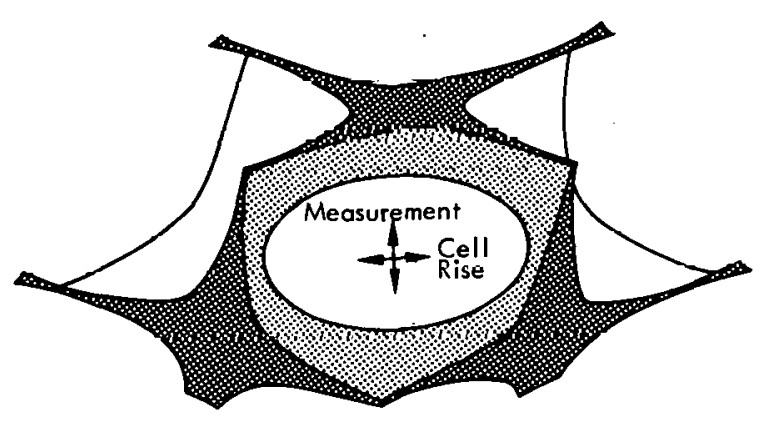

Figure 8. ONE-DIMENSIONAL REPRESENTATION OF A CARBON FOAM CELL. models of all employed test techniques. Data scatter for the CA results was much more consistent $-2.8 \%$ and $4.4 \%$ for the IIF and LF material, respectively. The RF terhnique gave results duviant, on the average, by $1.9 \%$ and $3.8 \%$ for the $\mathrm{HF}$ and LF foam.

GHP, CA, and RF data were compiled and reduced by regression analyses giving each observation equal statistical weight to produce a comprehensive thermal conductivity/temperature function. Summary results for the LF and HF carbon foam are 
Table 2

COMPARISON OF THERMAL-CONDUCTIVITY RESULTS FOR LOW.FIRED CARBON FOAM

\begin{tabular}{|c|c|c|c|c|c|c|c|c|}
\hline \multirow[b]{2}{*}{ Method } & \multirow{2}{*}{$\begin{array}{c}\text { Mean } \\
\text { Temperature, T } \\
\text { (K) }\end{array}$} & \multicolumn{2}{|c|}{$\begin{array}{c}\text { Thermal } \\
\text { Conductivity, } \lambda \\
\text { (watt/m-K) }\end{array}$} & \multirow{2}{*}{\multicolumn{2}{|c|}{$\begin{array}{l}\text { Polynomial Function } \\
\text { of } T \text { for } \lambda\end{array}$}} & \multirow{2}{*}{$\begin{array}{c}\text { Standard } \\
\text { Deviation } \\
\text { of Fit, } \\
\sigma(3)\end{array}$} & \multirow{2}{*}{$\begin{array}{l}\text { Percent } \\
\text { Deviation, } \\
\sigma / \bar{\lambda} \times 10^{2}\end{array}$} & \multirow{2}{*}{$\begin{array}{c}\text { Correlation } \\
\text { Coefficient } \\
r(4)\end{array}$} \\
\hline & & Observed (1) & Calculated $(2)$ & & & & & \\
\hline Guarded & 324 & 0.173 & 0.167 & \multicolumn{2}{|c|}{$\lambda=a_{1} T+a_{0}$} & 0.021 & 7.3 & 0.937 \\
\hline \multirow[t]{15}{*}{ Hot Plate } & 365 & 0.190 & 0.183 & $a_{1} \times 10^{4}$ & $a_{0} \times 10^{2}$ & & & \\
\hline & 373 & - & 0.186 & 3.98 & 3.84 & . & & \\
\hline & 469 & 0.228 & 0.224 & & & & & \\
\hline & 473 & $\cdot$ & 0.262 & & & & & \\
\hline & 530 & 0.275 & 0.249 & & & & & \\
\hline & 573 & - & 0.266 & & & & & \\
\hline & 574 & 0.236 & 0.266 & & & & & \\
\hline & 669 & 0.295 & 0.304 & & & & & \\
\hline & · 673 & - & 0.306 & & & & & \\
\hline & 675 & 0.298 & 0.306 & . & & & & \\
\hline & 763 & 0.315 & 0.342 & & & & & \\
\hline & 773 & - & 0.345 & & & & & \\
\hline & 779 & 0.337 & 0.348 & & & & & \\
\hline & 871 & 0.421 & 0.384 & & & & & \\
\hline & 979 & 0.434 & 0.428 . & & & & & \\
\hline Comparative & 476 & 0.307 & 0.285 & 2.76 & 15.4 & 0.016 & 4.4 & 0.927 \\
\hline \multirow[t]{6}{*}{ Apparatus } & 524 & 0.292 & 0.298 & & & & & \\
\hline & 539 & 0.325 & 0.302 & & & & & \\
\hline & 573 & 0.316 & 0.312 & & & & & \\
\hline & 616 & 0.308 & 0.323 & & & & & \\
\hline & 661 & 0.326 & 0.336 & & & & & \\
\hline & 673 & & 0.339 & & & & & \\
\hline
\end{tabular}

(1) Value based on an indlvidual observation.

(2) Value computed by regression analysis.

(3) $\sigma=\left|\frac{(\Sigma \lambda \text { obs }-\Sigma \lambda c a l c)^{2}}{i-p-1}\right|^{1 / 2}$, , where " $i$ " represents the number of data pairs and " $p$ " the degree of the palynomial function.

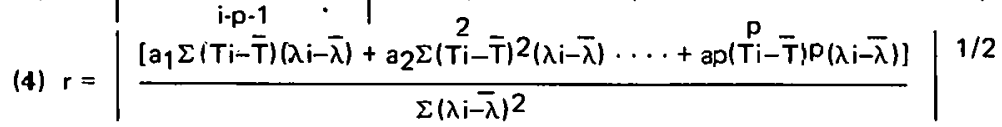


Table 2 (Continued)

\begin{tabular}{|c|c|c|c|c|c|c|c|c|c|c|}
\hline \multirow[b]{2}{*}{ Method } & \multirow{2}{*}{$\begin{array}{c}\text { Mean } \\
\text { Temperature, } \mathbf{T} \\
\text { (K) }\end{array}$} & \multicolumn{2}{|c|}{$\begin{array}{l}\text { Thermal } \\
\text { Conductivity, } \lambda \\
\text { 'watt } / \mathrm{m}-\mathrm{K} \text { ) }\end{array}$} & \multirow{2}{*}{\multicolumn{4}{|c|}{$\begin{array}{l}\text { Polynomial Furiction } \\
\text { of } T \text { for } \lambda\end{array}$}} & \multirow{2}{*}{$\begin{array}{c}\text { Standard } \\
\text { Deviation } \\
\text { of Fit, } \\
\sigma^{(3)}\end{array}$} & \multirow{2}{*}{$\begin{array}{l}\text { Percent } \\
\text { Deviation, } \\
\sigma / \bar{\lambda} \times 10^{2}\end{array}$} & \multirow{2}{*}{$\begin{array}{c}\text { Correlation } \\
\text { Coefficient, } \\
r(4)\end{array}$} \\
\hline & & Observed $(1)$ & Catculated (2) & & & & & & & \\
\hline Comparative & 721 & 0.378 & 0.352 & & & . & & & & \\
\hline \multirow[t]{15}{*}{ Apparatus } & 753 & 0.388 & 0.361 & & & & & & & \\
\hline & 773 & $\therefore$ & $0.36 ?$ & & & & & & & \\
\hline & 810 & 0.403 & $0.37 ?$ & & & & & & & \\
\hline & 843 & 0.379 & 0.386 & & & & & & & \\
\hline & 873 & - & 0.394 & & & & & & & \\
\hline & 898 & 0.412 & $0.40 \AA$ & & & & & & & \\
\hline & 927 & 0.388 & 0.409 & & & & & & . & \\
\hline & 957 & 0.440 & $0.41^{\top}$ & & & & & & & \\
\hline & 973 & 0.428 & 0.422 & & & & & & & \\
\hline & 1022 & 0.434 & 0.435 & & & & & & & \\
\hline & 1073 & - & 0.450 & & & & & & & \\
\hline & 1113 & 0.473 & 0.460 & & & & & & & \\
\hline & 1141 & 0.471 & 0.468 & & & & & & & \\
\hline & 1173 & 0.492 & $0.47^{7}$ & & & & & & & \\
\hline & 1187 & 0.460 & 0.48 & & & & & & & \\
\hline \multirow[t]{2}{*}{ Radial Flow } & 1200 & 0.788 & 0.795 & $\lambda=a_{4}$ & $T^{4}+a_{3} T$ & $3+a_{2} T^{2}$ & $+a_{1} T+a_{0}$ & 0.028 & 1.9 & 0.997 \\
\hline & 1273 & . & 0.802 & $a_{4} \times 10^{13}$ & $a_{3} \times 10^{9}$ & $a_{2} \times 10^{6}$ & $a_{1} \times 10^{2} a_{0}$ & & & \\
\hline \multirow[t]{8}{*}{. } & 1391 & 0.853 & 0.839 & 3.75 & -2.78 & 8.11 & $-1.00 \quad 5.19$ & & & \\
\hline & 1473 & 0.863 & 0.878 & & & & & & & \\
\hline & 1523 & - & 0.908 & & & & & & & \\
\hline & 1609 & 0.973 & 0.965 & & & & & & & \\
\hline & 1661 & 0.992 & 1.00 & & & & & & & \\
\hline & 1726 & 1.05 & 1.05 & & & & & & & \\
\hline & 1773 & - & 1.09 & & & & & & & \\
\hline & 1814 & 1.16 & 1.13 & & & & & & & \\
\hline
\end{tabular}


Table 2 (Continued)

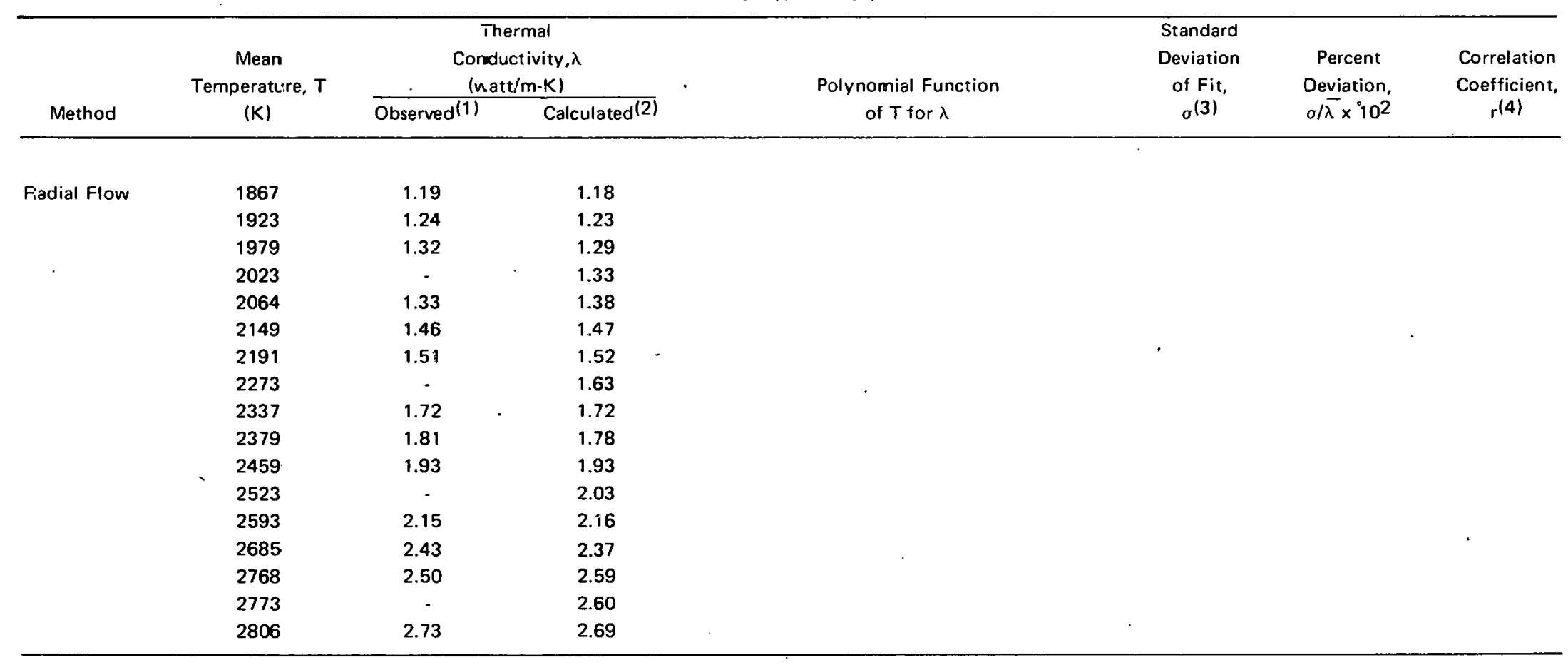


Table 3

COMPARISON OF THERMAL-CONDUCTIVITY RESULTS

FOR HICH-FIRED CARBON FOAM

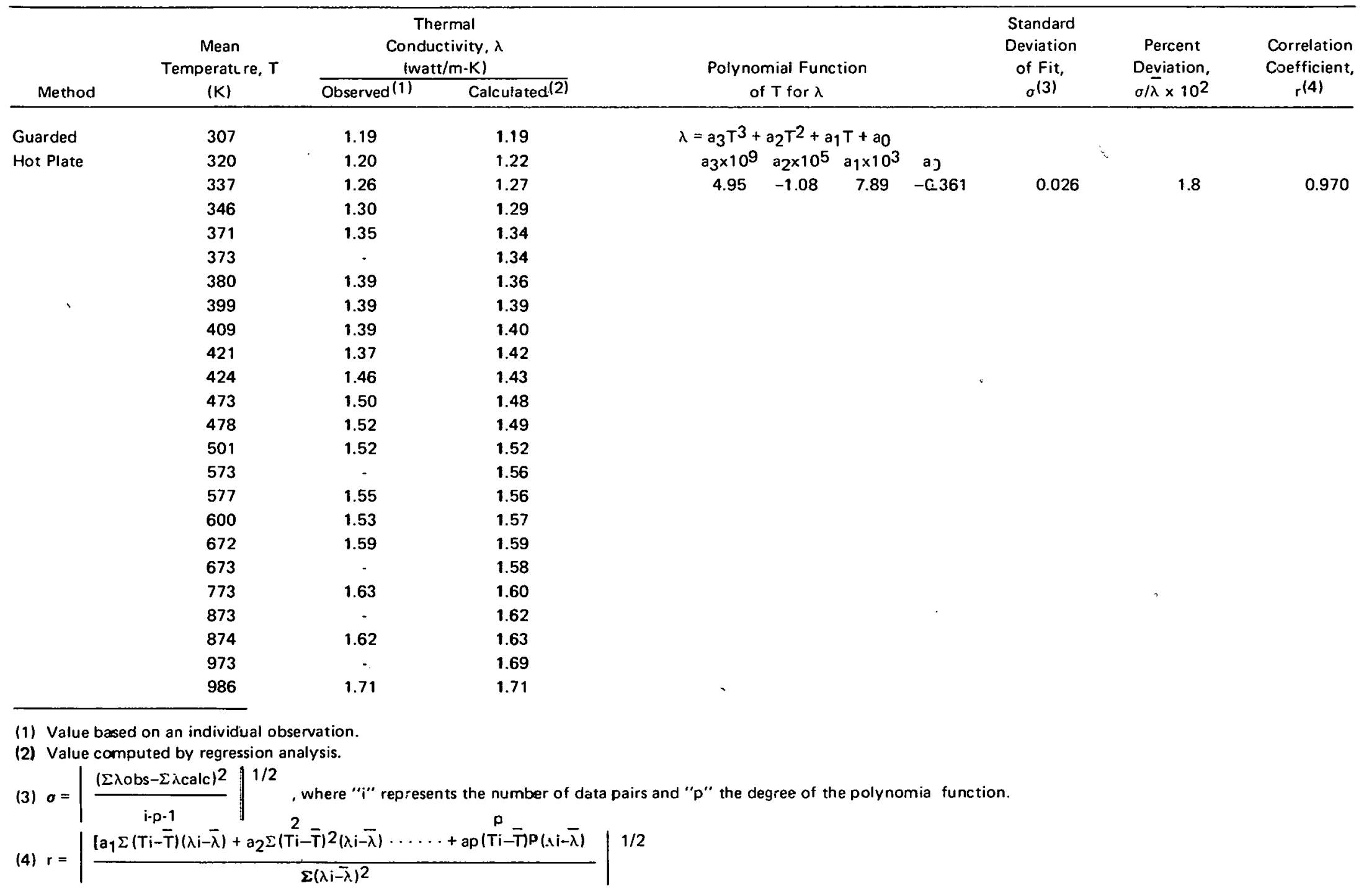


Table 3 (continued)

\begin{tabular}{|c|c|c|c|c|c|c|c|c|c|c|c|}
\hline \multirow[t]{2}{*}{ Vethod } & \multirow[t]{2}{*}{$\begin{array}{c}\text { Vean } \\
\text { Temperature, } T \\
\text { (K) }\end{array}$} & \multicolumn{2}{|c|}{$\begin{array}{c}\text { Thermal } \\
\text { Conductivity, } \lambda \\
\text { (wa1t/m-K) }\end{array}$} & \multicolumn{5}{|c|}{$\begin{array}{c}\text { Polynomial Function } \\
\text { of } T \text { for } \lambda\end{array}$} & \multirow[t]{2}{*}{$\begin{array}{c}\text { Standard } \\
\text { Deviation } \\
\text { of Fit, } \\
\sigma(3)\end{array}$} & \multirow[t]{2}{*}{$\begin{array}{l}\text { Percent } \\
\text { Deviation, } \\
\sigma / \bar{\lambda} \times 10^{2}\end{array}$} & \multirow[t]{2}{*}{$\begin{array}{c}\text { Correlation } \\
\text { Coefficient, } \\
r^{(4)}\end{array}$} \\
\hline & & & & & a $3 \times 10^{9}$ & $a_{2} \times 10^{5}$ & $a_{1} \times 10^{5}$ & ao & & & \\
\hline Comparative & 395 & 1.61 & 1.55 & & 1.51 & -0.429 & 4.03 & 0.531 & 0.049 & 2.8 & 0.677 \\
\hline \multirow[t]{11}{*}{ Apparatus } & 404 & 1.47 & 1.56 & & & & & & & & \\
\hline & 436 & 1.56 & 1.60 & & & & & & & & \\
\hline & 457 & 1.70 & 1.62 & & & & & & & & \\
\hline & 473 & - & 1.63 & & & & & & & & \\
\hline & 483 & 1.59 & 1.65 & & & & & & & & \\
\hline & 514 & 1.75 & 1.69 & & & & & & & & \\
\hline & 545 & 1.65 & 1.70 & & & & & & & & \\
\hline & 573 & - & 1.71 & & & & & & & & \\
\hline & 607 & 1.68 & 1.73 & & & & & & 0.076 & 3.8 & 0.975 \\
\hline & 637 & 1.79 & 1.75 & & & & & & & & \\
\hline & 673 & - & 1.76 & & & & & & & & \\
\hline \multirow{16}{*}{. } & 697 & 1.80 & 1.77 & & & & & & & & \\
\hline & 728 & 1.74 & 1.77 & & & & & & & & \\
\hline & 756 & 1.80 & 1.78 & & & & & & & & \\
\hline & 773 & - & 1.78 & & & & & & & & \\
\hline & 789 & 1.79 & 1.78 & & & & & & & & \\
\hline & 815 & 1.79 & 1.78 & & & & & & & & \\
\hline & 846 & 1.75 & 1.78 & & & & & & & & \\
\hline & 873 & $\cdot$ & 1.78 & & & & & & & & \\
\hline & 905 & 1.79 & 1.78 & & & & & & & & \\
\hline & 934 & 1.74 & 1.78 & & & & & & & & \\
\hline & 923 & $\cdot$ & 1.78 & & & & & & & & \\
\hline & 995 & 1.81 & 1.78 & : & & & & & & & \\
\hline & 1025 & 1.84 & 1.78 & . & & & & & & & \\
\hline & 1055 & 1.74 & 1.78 & & & & & & & & \\
\hline & 1073 & - & 1.78 & & & & & & & & \\
\hline & 1117 & 1.74 & 1.78 & & & & & & & & \\
\hline
\end{tabular}




\begin{tabular}{|c|c|c|c|c|c|c|c|c|c|c|c|}
\hline \multirow[b]{2}{*}{ Method } & \multirow{2}{*}{$\begin{array}{c}\text { Mean } \\
\text { Temperature, T } \\
\text { (K) }\end{array}$} & \multicolumn{2}{|c|}{$\begin{array}{c}\text { Thermal } \\
\text { Conductivity, } \lambda \\
\text { (watt } / \mathrm{m}-\mathrm{K} \text { ) }\end{array}$} & \multirow{2}{*}{\multicolumn{5}{|c|}{$\begin{array}{l}\text { Polynomial Function } \\
\text { of } T \text { for } \lambda\end{array}$}} & \multirow[t]{2}{*}{$\begin{array}{c}\text { Staridard } \\
\text { Deviation } \\
\text { of Fit, } \\
\sigma .31\end{array}$} & \multirow[t]{2}{*}{$\begin{array}{l}\text { Percent } \\
\text { Deviation, } \\
\sigma / \bar{\lambda} \times 10^{2}\end{array}$} & \multirow[t]{2}{*}{$\begin{array}{c}\text { Correlation } \\
\text { Coefficient, } \\
\quad \text { (4) }\end{array}$} \\
\hline & & Observed (1) & Calculated(2) & & & & & & & & \\
\hline \multirow[t]{32}{*}{ Radial Flow } & 1023 & - & 1.48 & $\lambda=a_{C}$ & $T^{4}+a_{3} T$ & $3+a_{2} T^{2}$ & $+a_{1} T+a$ & & & & \\
\hline & 1082 & 1.67 & 1.58 & $.04 \times 10^{13}$ & a $3 \times 10^{9}$ & $32 \times 10^{5}$ & $a_{1} \times 10^{2}$ & ao & & & \\
\hline & 1185 & 1.64 & 1.66 & $-\overline{5} .69$ & 5.24 & -1.44 & 1.70 & -1.59 & & & \\
\hline & 1235 & 1.68 & 1.69 & & & & & & & & \\
\hline & 1273 & - & 1.65 & & & & & & & & \\
\hline & 1305 & 1.71 & 1.72 & & & & & & & & \\
\hline & $\uparrow 359$ & 1.85 & 1.74 & & & & & & & & \\
\hline & 1423 & 1.73 & 1.77 & & & & & & & & \\
\hline & 1472 & 1.83 & 1.78 & & & & & & & & \\
\hline & 1523 & & 1.71 & & & & & & & & \\
\hline & 1605 & 1.79 & 1.83 & & & & & & & & \\
\hline & 1667 & 1.87 & 1.86 & & & & & & & & \\
\hline & 1733 & 1.88 & 1.90 & & & & & & & & \\
\hline & 1773 & . & 1.79 & & & & & & & & \\
\hline & 1809 & 2.00 & 1.94 & & & & & & & & \\
\hline & 1863 & 1.97 & 1.99 & & & & & & & & \\
\hline & 1911 & 1.98 & 2.03 & & & & & & & & \\
\hline & 1967 & 2.06 & 2.09 & & & & & & & & \\
\hline & 2023 & - & 1.98 & & & & & & & & \\
\hline & 2051 & 2.29 & 2.18 & & & & & & & & \\
\hline & 2116 & 2.30 & 2.27 & & & & & & & & \\
\hline & 2178 & 2.37 & 2.36 & & & & & & & & \\
\hline & 2259 & 2.53 & 2.48 & & & & & & & & \\
\hline & 2273 & - & 2.29 & & & & & & & & \\
\hline & 2332 & 2.52 & 2.60 & & & & & & & & \\
\hline & 2405 & 2.55 & 2.73 & & & & & & & & \\
\hline & 2443 & 2.73 & 2.79 & & & & & & & & \\
\hline & 2502 & 3.02 & 2.90 & & & & & & & & \\
\hline & 2523 & - & 2.66 & & & & & & & & \\
\hline & 2605 & 3.19 & 3.07 & & & & & & & & \\
\hline & 2773 & - & 3.00 & & & & & & & & \\
\hline & 2776 & 3.29 & 3.33 & & & & & & & & \\
\hline
\end{tabular}




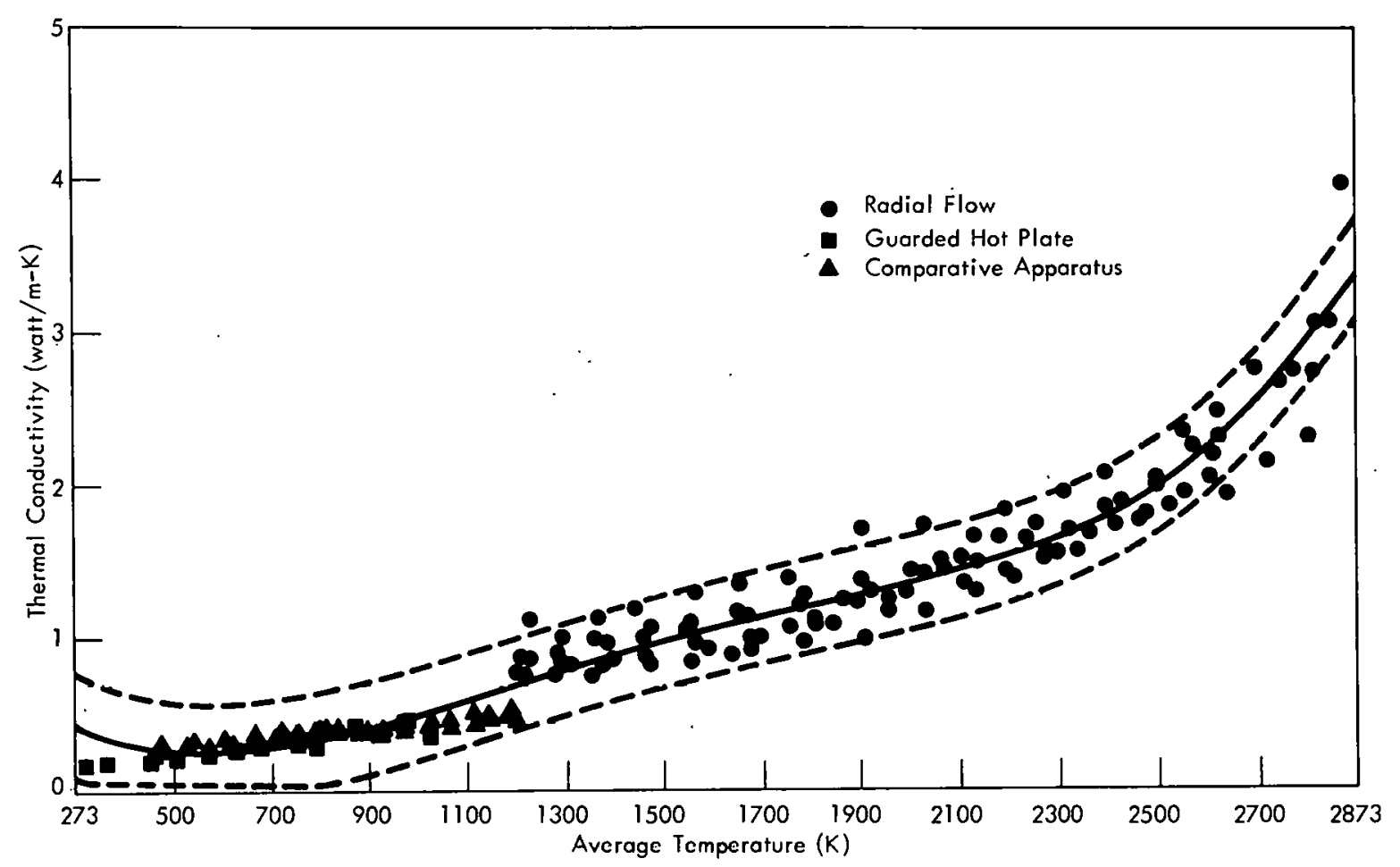

Figure 9. THERMAL CONDUCTIVITY OF LOW-FIRED CARBON FOAM (STANDARD $90 \%$ TL).

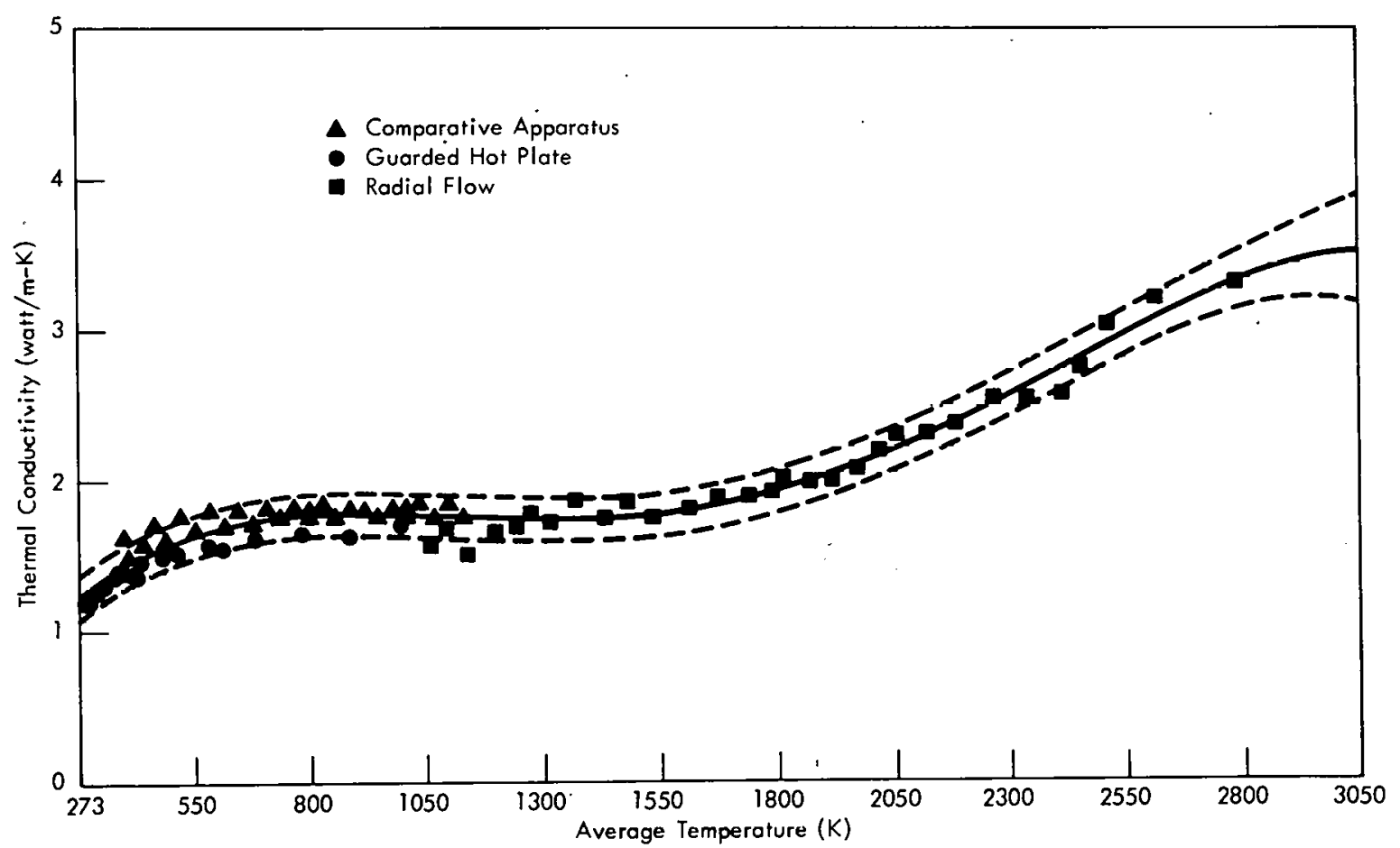

Figure 10. THERMAL CONDUCTIVITY OF HIGH-FIRED CARBON FOAM (STANDARD 90\% TL). 


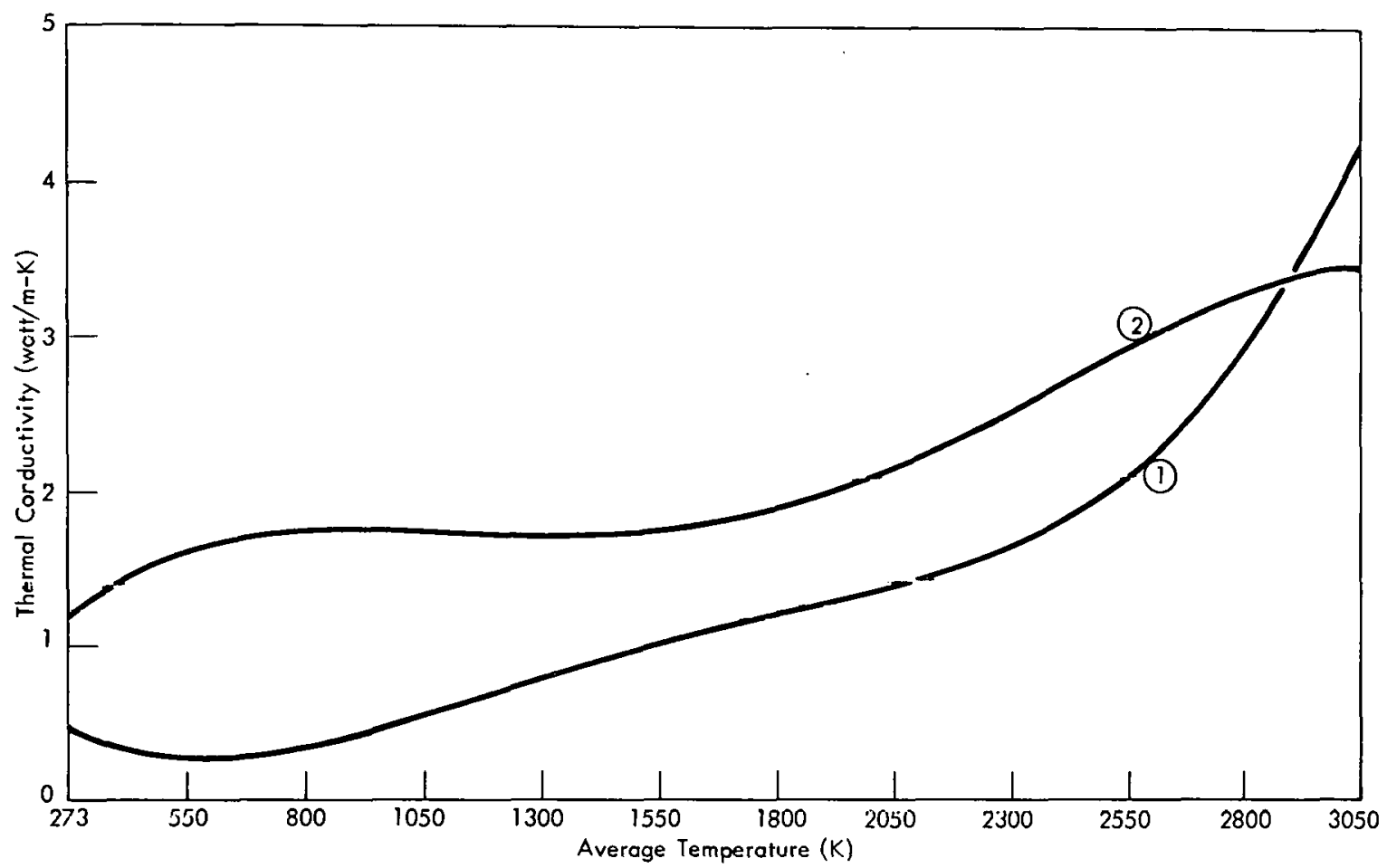

Figure 11. COMPARISON OF THERMAL CONDUCTIVITY FOR LOW-FIRED, (1). AND HIGH-FIRED, (2), CARBON FOAM.

compiled in Table 4. All observations, the computed trend line, and $90 \%$ tolerance limits are displayed in Figures 9 and 10 wherein the separate techniques are differentiated symbolically. As indicated in Table 4, the percent deviation of the composite CA, GHP, and $R F$ data about the computed regression lines are, respectively, 8.1 and $4.7 \%$ for the $L F$ and $\mathrm{HF}$ materials. A comparison of the LF and HF results is provided in Figure 11. HF results were higher by approximately $320 \%$ at $298 \mathrm{~K}, 165 \%$ at $1273 \mathrm{~K}, 79 \%$ at $1773 \mathrm{~K}$, and $46 \%$ at $2523 \mathrm{~K}$.

Consideration of the results given in Tables 2 and 3 and depicted in Figures 9 and 10 shows good agreement between the GHP and CA results within the $400-1000 \mathrm{~K}$ overlap region and reasonable compatibility between the aggregate CA/GHP and RF data groupings, considering that in the 1000 to $1300 \mathrm{~K}$ interfacial region each technique manifests the highest levels of measurement error. Specifically, the CA, GHP, and RF techniques (respectively) suffered in this region due to thermocouple noise/heat losses and large. absolute pyrometric errors. These effects do bias the data points lower for the CA/GHP and higher for the RF methods; but, when all data sets are aggregated (Table 4), the effect upon the composite regression line is minimized.

\section{Interprétation}

Individual GHP and CA thermal conductivity values were obtained on the basis of multiple pairs of temperature determinations; whereas, each RF value was based on two pyrometer readings which defined the temperature gradient. GHP and CA thermal transport distances 
Table 4

REPRESENTATIVE THERMAL CONDUCTIVITY RESULTS FOR CARBON FOAM

(Composite of All Methods: GHP, CA, and RF)

\begin{tabular}{|c|c|c|c|c|c|c|c|c|c|c|}
\hline $\begin{array}{l}\text { Previous } \\
\text { Heat Treatment } \\
\text {-emperature } \\
\text { (K) }\end{array}$ & $\begin{array}{c}\text { Mean } \\
\text { Temperature, } T \\
\text { (K) }\end{array}$ & $\begin{array}{c}\text { Computed } \\
\text { Thermal } \\
\text { Conductivity, } \lambda \\
\text { (wat } / \mathrm{m} \cdot \mathrm{K} \text { ) }\end{array}$ & \multicolumn{5}{|c|}{$\begin{array}{c}\text { Polynomial Function of } \\
\qquad \operatorname{tor} \lambda(1)\end{array}$} & \multirow[t]{2}{*}{$\begin{array}{c}\text { Standard } \\
\text { Deviation } \\
\text { of Fit, } \\
\sigma(2)\end{array}$} & \multirow[t]{2}{*}{$\begin{array}{c}\text { Percent } \\
\text { Deviation, } \\
\sigma / \bar{\lambda} \times 10^{2}\end{array}$} & \multirow[t]{2}{*}{$\begin{array}{c}\text { Correlation } \\
\text { Coefficient, } \\
r(3)\end{array}$} \\
\hline 1273 & 298 & 0.290 & & $=a_{4} T^{4+a_{3}}$ & $T^{3}+a_{2} T^{2}$ & $\operatorname{ra}_{1} T+a_{0}$ & & & & \\
\hline \multirow[t]{10}{*}{ (low fired) } & 523 & 0.274 & $a_{4} \times 10^{13}$ & $a_{3} \times 10^{10}$ & $a_{2 \times 10^{6}}$ & $a_{1} \times 10^{3}$ & $a_{0}$ & 0.055 & 8.1 & 0.991 \\
\hline & 773 & 0.374 & 1.17 & -6.69 & 1.62 & -1.08 & 0.485 & & & \\
\hline & 1023 & 0.481 & & & & & & & & \\
\hline & 1273 & 0.653 & & & & & & & & \\
\hline & 1523 & 0.851 & & & & & & & & \\
\hline & 1773 & 1.07 & & & & & & & & \\
\hline & 2023 & 1.33 & & & . & & & & & \\
\hline & 2273 & 1.64 & & & & & & & & \\
\hline & 2523 & 2.04 & & & & & & & & \\
\hline & 2773 & 2.58 & & & & & & & & \\
\hline \multirow{11}{*}{$\begin{array}{c}3273 \\
\text { (high fired) }\end{array}$} & 298 & 1.22 & -3.73 & -18.0 & -2.25 & 4.28 & 0.198 & 0.084 & 4.7 & 0.956 \\
\hline & 523 & 1.61 & & & & & & & & \\
\hline & 773 & 1.75 & & & & & & & & \\
\hline & 1023 & 1.75 & & & & & & & & \\
\hline & 1273 & 1.73 & & & & & & & & \\
\hline & 1523 & 1.76 & & & & & & & & \\
\hline & 1773 & 1.91 & & & & & & & & \\
\hline & 2023 & 2.18 & & & & & & & & \\
\hline & 2273 & 2.55 & & & & & & & & \\
\hline & 2523 & 2.98 & & & & & & & & \\
\hline & 2773 & $3 .: 6$ & & & & & & & & \\
\hline
\end{tabular}

(1) Obtained by regression andysis of all observations carrying equal statistical weight.

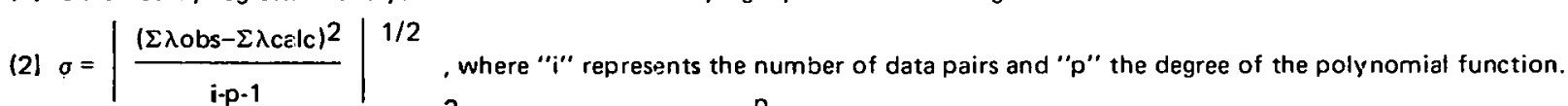

(3) $r=\left|\frac{\left[a_{1} \Sigma(T i-\bar{T})(\lambda i-\bar{\lambda})+a_{2} \Sigma(T i-\bar{T})^{2}(\lambda i-\bar{\lambda}) \cdots \cdots+a p(T i-\bar{T}) p(\lambda i-\bar{\lambda})\right]}{\Sigma(\lambda i-\bar{\lambda})^{2}}\right|^{1 / 2}$ 
ranged from 9.53 to $25.4 \mathrm{~mm}$; whereas, the $R F$ technique employed paths ranging from 1.55 to $4.75 \mathrm{~mm}$. Accordingly, it should be observed that the CA/GHP-RF interfacial region $(1000-1300 \mathrm{~K})$ may be described collectively as a macro-micro union which contributes to the $\lambda$ value biases between methods. The considerable aggregate imprecision of all methods is thought to be attributable, in large part, to gross material nonhomogeneity, as the porosimetric findings (Table 1) connote. Repetitive RF tests were employed in an attempt to segregatc, and thus differentiate, between the absolute measurement error and that due primarily to material nonuniformity. The results for LF carbon foam are displayed by the graph of Figure 12 with identical nonlinear regression analyses being applied to four individual (dashed) determinations to generate a composite (solid) regression line. Covariance analyses of the dashed trend lines about the composite (regression) line of Figure 12 were conducted to compute the adjusted $90 \%$ tolerance limits, as portrayed in Figure 13 , with extrapolation to $273 \mathrm{~K}$ included but admittedly invalid below $600 \mathrm{~K}$. On the presumption of a normal distribution of data pairs about the solid regression line of Figure 12, the basis for allocating sources of error between method and material would be sound. However, the dashed trend lines predominantly lie above the computed regression line of Figure 12, which clouds the issue. On the other hand, assuming an abnormal (non-Gaussian) distribution for the observed data and comparing tolerance intervals of Figures 9 and 10 on a quantitative basis with that of Figure 13 leads to the conclusion that material nonhomogeneity and not the method(s) is the major contributor to measurement imprecision.

Stated accuracies (17) of the CA and GHP techniques are, respectively, \pm 5 to $\pm 10 \%$ and \pm 2 to $\pm 5 \%$, absolute. For nonhomogeneous materials, these ranges serve only as rough guidelines. All thermal-conductivity results of insulation materials in the range of carbon foam may be viewed as somewhat provisional in the absence of well-characterized standards for comparison and calibration.

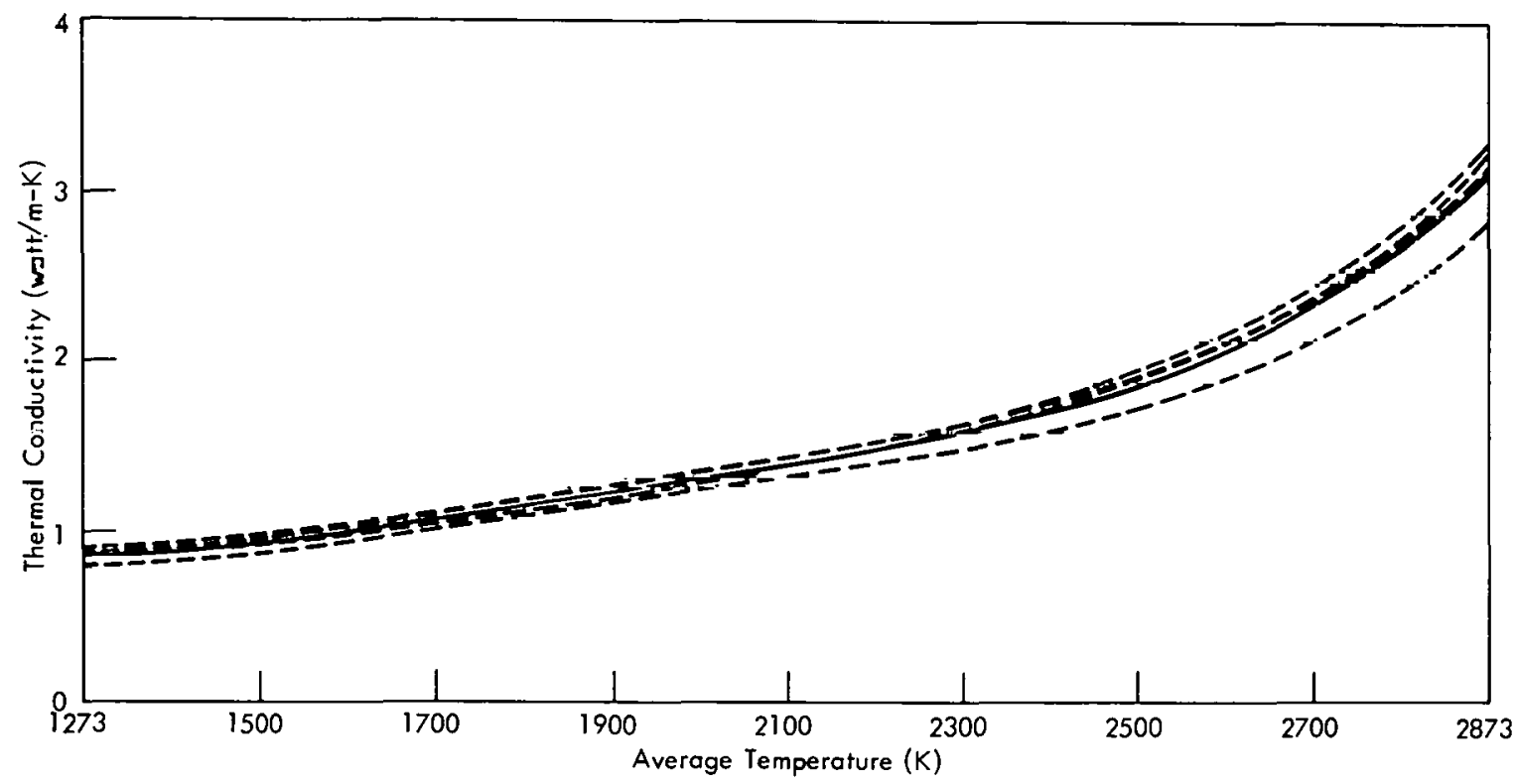

Figure 12. ILLUSTRATION OF THE AGgREgAtE REPEATABILITY OF THE RADIAL-FLOW TECHNIQUE FOR CARBON FOAM. 


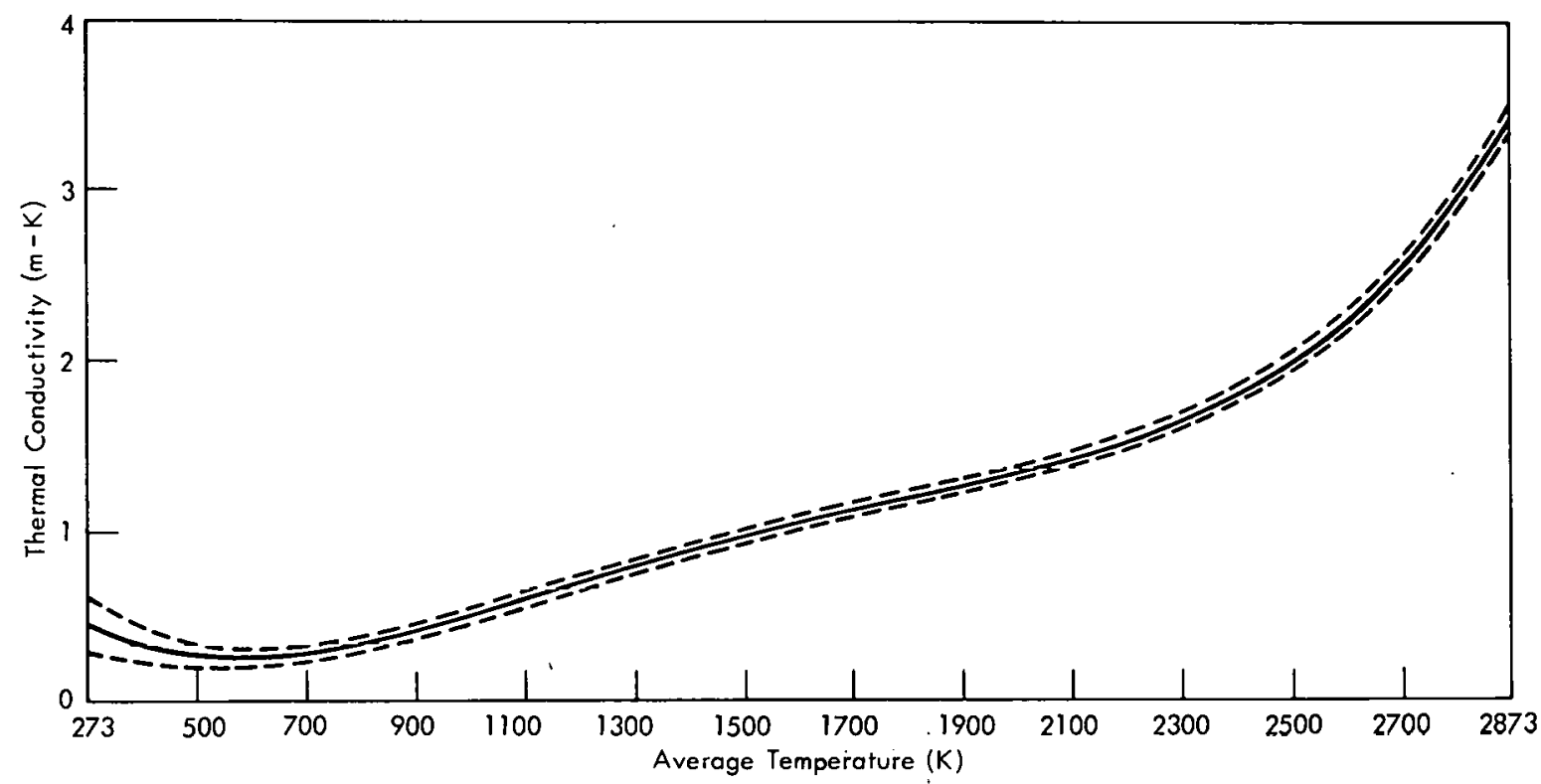

Figure 13. THERMAL CONDUCTIVITY OF LOW-FIRED CARBON FOAM WITH AN ADJUSTED 90\% TOLERANCE LIMIT.

\section{COMPARISON WITH OTHER FINDINGS}

It is oftentimes enlightening and always interesting to compare test results for a given material with similar data exuded from other experimental findings and particularly those hybridized by semitheoretical treatments.

Comparison with the findings of Sandia Laboratories based on both experimental results by the flash diffusivity technique on Y-12-produced 155 and $178 \mathrm{~kg} / \mathrm{m}^{3} \operatorname{LF}$ material $(18,19)$ and with experimental results from Battelle Memorial Institute's stead.y-state apparatus for $94 \mathrm{~kg} / \mathrm{m}^{3}$ carbon foam, as given in Table 5, shows general trends for the LF material that concur with the mathematical model which is herein proposed (Table 4). Corll's experimental data, zero-time effective conductivity, and computed pore contributions for selected sizes are exhibited in Figure 14 without further explanation. The curves were obtained by highly sophisticated, but plausible, analyses which are fully described in his paper.(19)

\section{CONCLUSIONS AND RECOMMENDATIONS}

After several refinements of measurement and data-reduction techniques, particularly with respect to the "nonstandard" radial flow approach, this characterization has yielded what is believed to be carefully acquired, objectively treated values of thermal conductivity as reliable as any which have been, heretofore, reported. $Y-12$ 's findings are acknowledged to be provisional and potentially at variance with data obtained by other test techniques. Unfortunately, at high temperatures, all methods are "nonstandard", because none bear the ASTM certification or even general acceptance (due, primarily, to scant confirmatory or 
Table 5

THERMAL CONDUCCTIVITY RESULTS FOR LOW-FIRED CARBON FOAM

\begin{tabular}{|c|c|c|c|c|c|c|}
\hline Laboratory $(1)$ & Method (2) & $\begin{array}{l}\text { Source of } \\
\text { Material }\end{array}$ & $\begin{array}{l}\text { Material } \\
\text { Density } \\
\left(\mathrm{kg} / \mathrm{m}^{3}\right)\end{array}$ & $\begin{array}{l}\text { Direction of } \\
\text { Measurement }\end{array}$ & $\begin{array}{l}\text { Temperature (3) } \\
\text { (K) }\end{array}$ & $\begin{array}{l}\text { Thermal } \\
\text { Conductivity }(3) \\
\text { (watt } / \mathrm{m}-\mathrm{K} \text { ) }\end{array}$ \\
\hline Sandia & Flassh niffusivity & $\begin{array}{l}\text { Rendix - } \\
\text { Kansas City }\end{array}$ & 94 & $\begin{array}{l}\text { Parallel to } \\
\text { Direction of } \\
\text { Cell Mise }\end{array}$ & $\begin{array}{l}1173 \\
1573 \\
18 / 3 \\
2173 \\
24 / 3 \\
2573\end{array}$ & $\begin{array}{l}0.4 \\
0.6 \\
0.8 \\
1.21 \\
1.4 \\
2.4\end{array}$ \\
\hline $\begin{array}{l}\text { Battelie } \\
\text { Memorial } \\
\text { Institute }\end{array}$ & $\begin{array}{l}\text { Steady-State } \\
\text { Longitudinal } \\
\text { Heat Flow } \\
\text { Apparatus }\end{array}$ & $\begin{array}{l}\text { Bendix - } \\
\text { Kansas City }\end{array}$ & $y_{4}$ & $\begin{array}{l}\text { Parallel to } \\
\text { Direction of } \\
\text { Cell Rise }\end{array}$ & $\begin{array}{l}1173 \\
1573 \\
1873 \\
2173 \\
2473 \\
2573\end{array}$ & $\begin{array}{l}0.5 \\
0.6 \\
0.9 \\
1.3 \\
1.0 \\
3.4\end{array}$ \\
\hline Sandia & Flash Diffusivity & $\begin{array}{l}\text { Bendix - } \\
\text { Kansas City }\end{array}$ & 94 & $\begin{array}{l}\text { Perpendicular } \\
\text { to Direction of } \\
\text { Cell Rise }\end{array}$ & $\begin{array}{l}1273 \\
1573 \\
1873 \\
2173 \\
2373 \\
2473 \\
25 \overline{3} 3\end{array}$ & $\begin{array}{l}0.2 \\
0.3 \\
0.5 \\
0.7 \\
0.8 \\
1.0 \\
1.1\end{array}$ \\
\hline $\begin{array}{l}\text { Battelle } \\
\text { Memorial } \\
\text { Institute }\end{array}$ & $\begin{array}{l}\text { Steady-State } \\
\text { Longitudinal } \\
\text { Heat Flow } \\
\text { Apparatus }\end{array}$ & $\begin{array}{l}\text { Bendix - } \\
\text { Kansas C.ity }\end{array}$ & 94 & $\begin{array}{l}\text { Perpendicular } \\
\text { to Direction of } \\
\text { Cell Rise }\end{array}$ & $\begin{array}{l}1273 \\
1573 \\
1873 \\
2173 \\
2373 \\
2473 \\
2573\end{array}$ & $\begin{array}{l}0.3 \\
0.4 \\
0.7 \\
0.9 \\
1.2 \\
1.4 \\
2.1\end{array}$ \\
\hline Sạndiạ & Flash Diffusivity & $\begin{array}{l}\text { Oak Ridge } \\
\text { Y-12 Plant }\end{array}$ & 155 & Undefined & $\begin{array}{r}773 \\
1023 \\
1273 \\
1523 \\
1673\end{array}$ & $\begin{array}{l}0.5 \\
0.8 \\
1.0 \\
1.3 \\
1.4\end{array}$ \\
\hline Sandia & Flash Diffusivity & $\begin{array}{l}\text { Oak Ridge } \\
\text { Y-12 Plant }\end{array}$ & 178 & Undefined & $\begin{array}{r}773 \\
1023 \\
1273 \\
15,23 \\
1623\end{array}$ & $\begin{array}{l}0.3 \\
0.4 \\
0.5 \\
0.8 \\
1.0\end{array}$ \\
\hline
\end{tabular}

(1) These data are reported by Rainhart ${ }^{(18)}$ and Corll. (19)

(2) Test environments not disclosed, but presumably were vacuum.

(3) Values obtained from graphical display and are, therefore, approximate. 


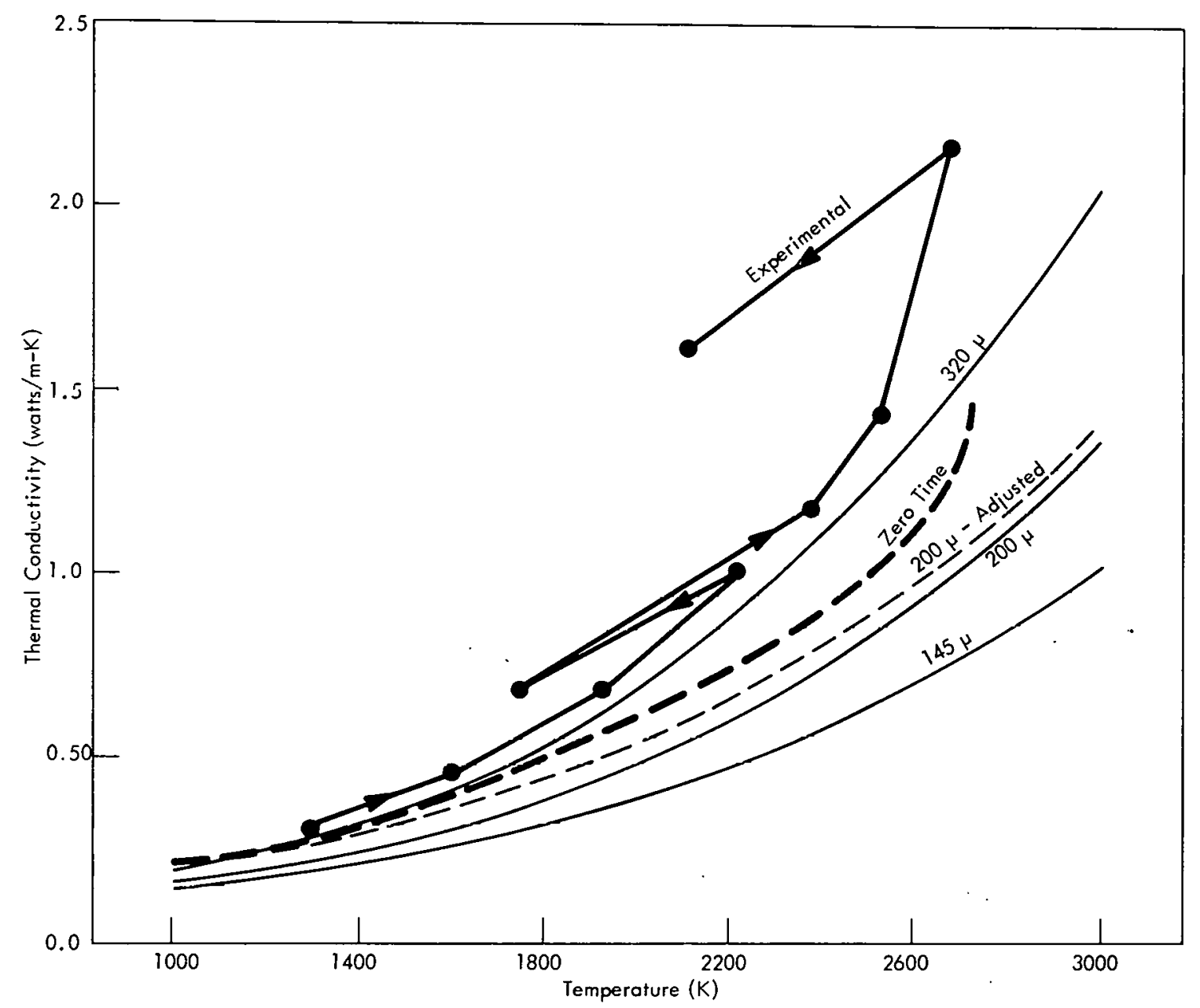

Figure 14. COMPARISON OF BATTELLE EXPERIMENTAL MEASUREMENTS AND SANDIA THEORETICAL CALCULATIONS FOR $94 \mathrm{~kg} / \mathrm{m}^{3}$ LOW.FIRED CARBON FOAM (AFTER CORLL(19)).

comparative analyses of similar materials), and because there is a lack of accepted standard reference materials. Unllil such time that carbon foam and other similar types of insulative materials are examined by a number of careful experimenters using diverse techniques and thorough documentation, questions about test accuracy, applicability, and reliability will prevail. 


\section{REFERENCES}

(1) Mitchell, C. V.; U S Patent 3,302,999; February 1967.

(2) McMillan, W. J.; U S Patent 3,342,555; September 1967.

(3) Googin, J. M. Napier, J. M., and Scrivner, M. E.; U S Patent 3,345,440; October 1967.

(4) McHenry, E. R. and Piper, E. L.; U S Patent 3,387,940; June 1968.

(5) Thoeni, A. K., et al; Carbon Foam-A Cellular Material for High Temperature Application, BDX-613-112; Bendix Corporation, Kansas City, Kanisds; January 1969.

(6) Sande, A. E., et al; Preparation and Properties of Carbon Foam, Y-1706; Union Carbide Corporation-Nuclear Division, Oak Ridge Y-12 Plant, Oak Ridge, Tennessee; March 23, 1970.

(7) ASTM C177-63; American Society for Testing and Materials, Philadelphia, Pennsylvania (1963).

(8) Tye, R. P.; The Art of Measuring Thermal Conductivity, Paper 68-523; 23rd ISA Conference, New York, New York (1968).

(9) Francis, R. K., et al; "Thermal Conductivity in Ceramic Metal Laminates", J Am Ceramic Soc, 43, p 560 (1960).

(10) Francl, J., et al; "Thermal Conductivity: IV, Apparatus for Determining Thermal Conductivity by a Comparative Method", J Am Ceramic Soc, 37, p 80 (1954).

(11) Fourier, J.; Theorie Analytical de al Chalver; Gauthier-Villars, Paris (1822), English translation by Freeman, Cambridge (1878).

(12) Wagner, P.; “Versatile High Temperature Furnace", Rev Scient Inst, 37, (8), p 1054 (1966).

(13) Wagner, P.; Equipment and Techniques for Measurements of Thermal Conductivity, Thermal Expansion, and Associated Properties Above $1000^{\circ} \mathrm{C}$; LA-DC-9545; December 1967.

(14) Wagner, P., et al; "The Thermal Conductivity of ZTA Graphite", Carbon, 5, p 271 (1967).

(15) Wagner, P.. et al; "The Thermal Conductivity of SX-5 Graphite", Carbon, 6, p 373 (1968).

(16) Wagner, P., et al; "Some Thermal Properties of a Polyfurfuryl Alcohol Bonded Graphite", Carbon, 7, p 273 (1969). 
(17) Tye, R. P.; Personal Communication, Dynatech R. D.

(18) Rainhart, L. G., et al; Development of Carbon Thermal Insulation for the Materials Test Vehicle (MTV-1) Program, SC-DR-70-924; Sandia Laboratories, Albuquerque, New Mexico; April 1971.

(19) Corll, J. A.; Concerning the High Temperature Thermal Conductivity of Carbon Foams, SC-RR-70-22; Sandia Laboratories, Albuquerque, New Mexico; September 1970. 


\section{ACKNOWLEDGEMENTS}

The authors wish to thank Barbara J. Handley of the Computer Technology Center who provided guidance in the area of data reduction and evaluation, Z. L. Ardary, Materials Engineering Development, who provided the material for this study, and Paul Wagner, LASL, who deserves a commendation for his advice and consultation toward the design and construction of the high-temperature radial-flow test apparatus. 


\section{DISTRIBUTION}

Atomic Energy Commission - Oak Ridge

Hickman, H. D.

Zachry, D. S., Jr

Oak Ridge Gaseous Diffusion Plant

Ward, M. E.

Wilcox, W. J., Jr

Winkel, R. A.

Oak Ridge Y-12 Plant

Ardary, Z. L.

Briscoe, O. W.

Burditt, R. B.

Burkhart, L. E.

Cagle, G. W.

Denny, A.

Ebert, T. H.

Fraser, R. J.

Keith, A.

Kite, H. T.

Lore, J. D. (15)

Lundin, M. I.

Marrow, G. B.

McLendon, J. D.

Phillips, L. R.

Pollock, C. B.

Reynolds, C. D.

Richards, H. L.

Rowan, J. H.

Schreyer, J. M.

Smith, R. D.

Weathersby, W. E.

Yạgi, W. J./Googin, .I. M

$Y-12$ Central Files (5)

$Y-12$ Central Files (master copy)

$Y-12$ Central Files (route copy)

$Y-12$ Central Files ( $Y-12 R C$ )

Paducah Gaseous Diffusion Plant

Levin, R. W.

In addition, this report is distributed in accordance with the category UC-25, Materials, as given in the USAEC Standard Distribution Lists for Unclassified Scientific and Technical Reports, TID-4500. 
HU. S. GOVERNMENT PRINTING OFFICE: 1974.748.189/63 